\title{
Continental anthropogenic primary particle number emissions
}

\author{
Pauli Paasonen ${ }^{1,2,3}$, Kaarle Kupiainen ${ }^{2,3}$, Zbigniew Klimont ${ }^{2}$, Antoon Visschedijk ${ }^{4}$, Hugo A. C. Denier van der Gon ${ }^{4}$, \\ and Markus Amann ${ }^{2}$ \\ ${ }^{1}$ Department of Physics, University of Helsinki, Helsinki, Finland \\ ${ }^{2}$ International Institute for Applied Systems Analysis (IIASA), Laxenburg, Austria \\ ${ }^{3}$ Finnish Environment Institute (SYKE), Helsinki, Finland \\ ${ }^{4}$ TNO, the Netherlands Organisation for Applied Scientific Research, Utrecht, the Netherlands
}

Correspondence to: Pauli Paasonen (pauli.paasonen@helsinki.fi)

Received: 16 December 2015 - Published in Atmos. Chem. Phys. Discuss.: 19 January 2016

Revised: 25 April 2016 - Accepted: 25 April 2016 - Published: 6 June 2016

\begin{abstract}
Atmospheric aerosol particle number concentrations impact our climate and health in ways different from those of aerosol mass concentrations. However, the global, current and future anthropogenic particle number emissions and their size distributions are so far poorly known. In this article, we present the implementation of particle number emission factors and the related size distributions in the GAINS (Greenhouse Gas-Air Pollution Interactions and Synergies) model. This implementation allows for global estimates of particle number emissions under different future scenarios, consistent with emissions of other pollutants and greenhouse gases. In addition to determining the general particulate number emissions, we also describe a method to estimate the number size distributions of the emitted black carbon particles. The first results show that the sources dominating the particle number emissions are different to those dominating the mass emissions. The major global number source is road traffic, followed by residential combustion of biofuels and coal (especially in China, India and Africa), coke production (Russia and China), and industrial combustion and processes. The size distributions of emitted particles differ across the world, depending on the main sources: in regions dominated by traffic and industry, the number size distribution of emissions peaks in diameters range from 20 to $50 \mathrm{~nm}$, whereas in regions with intensive biofuel combustion and/or agricultural waste burning, the emissions of particles with diameters around $100 \mathrm{~nm}$ are dominant. In the baseline (current legislation) scenario, the particle number emissions in $\mathrm{Eu}-$ rope, Northern and Southern Americas, Australia, and China decrease until 2030, whereas especially for India, a strong increase is estimated. The results of this study provide in-
\end{abstract}

put for modelling of the future changes in aerosol-cloud interactions as well as particle number related adverse health effects, e.g. in response to tightening emission regulations. However, there are significant uncertainties in these current emission estimates and the key actions for decreasing the uncertainties are pointed out.

\section{Introduction}

Aerosol particles affect both our health and the climate in many ways. These effects depend partly on the composition of the particles and partly on their sizes and concentrations (WHO, 2013; Stocker et al., 2013). Furthermore, different effects are linked to different metrics of concentration - mass and number. Because of the cubic relation between particle mass and diameter, $d_{\mathrm{p}}$, it is common that these metrics of concentration are dominated by particles with very different sizes. Aerosol number concentrations are typically dominated by particles in ultrafine particle (UFP) size range, with $d_{\mathrm{p}}<0.1 \mu \mathrm{m}$, or the smaller end, roughly $<0.3 \mu \mathrm{m}$, of fine particles (FP, here $0.1-2.5 \mu \mathrm{m}$ ). On the contrary, the mass concentration depends mostly on the larger and heavier, but typically fewer FP, with $d_{\mathrm{p}}>0.3 \mu \mathrm{m}$ (see Fig. 1 for schematic representation). Because the particles in different size ranges originate from different sources and atmospheric processes impact them differently, the particle number $(\mathrm{PN})$ concentrations and particle mass concentrations (PM, e.g. $\mathrm{PM}_{2.5}$ describing mass concentration of particles with $d_{\mathrm{p}}<2.5 \mu \mathrm{m}$ ) are often poorly correlated even if considering only station- 
ary measurements (e.g. Rodríguez et al., 2007; Rodríguez and Cuevas, 2007).

According to WHO (2013), there is increasing epidemiological evidence on the association between short-term exposures to ultrafine particles and cardiorespiratory health, as well as the health of the central nervous system. Clinical and toxicological studies indicate that the health effects of ultrafine particles are (in part) caused by different mechanisms than those of larger particles, such as $\mathrm{PM}_{2.5}$ or $\mathrm{PM}_{10}$ (WHO, 2013). Also the climate effects of aerosol particles depend on their size (Stocker et al., 2013). All particles can, depending on their chemical composition, either absorb solar radiation (mainly black carbon aerosol) or scatter it partly back to space. In addition to these so-called aerosol-radiation interactions, the particles with diameter close to or over $0.1 \mu \mathrm{m}$ can act as cloud condensation nuclei (CCN), i.e. they can form cloud droplets when the air mass moves upwards and cools down. Since the clouds efficiently reflect solar radiation back to space, these aerosol-cloud interactions have a significant cooling effect on our climate. One of the problems in assessing the total radiative forcing of aerosols is the non-linear relationships of these different interactions, e.g. depending on the initial sizes and atmospheric growth of black carbon particles, their warming effect due to light absorption can be turned over, either partly or entirely, by their ability to act as $\mathrm{CCN}$ and thus form cooling cloud droplets (e.g. Chen et al., 2010). The future reductions in anthropogenic emissions of aerosol and their precursors have been estimated to accelerate global warming (e.g. Wigley, 1989; Arneth et al., 2009; Makkonen et al., 2012; Westervelt et al., 2015). However, the changes in aerosol-cloud interactions have been so far (if not ignored) assessed by assuming similar relative changes in particle mass and number emissions, which leads to incorrect results if the actual size distributions of emitted particles change.

The ultrafine and fine particles originate from a number of sources and atmospheric processes. New particle formation (i.e. nucleation) produces particles with diameters below $2 \mathrm{~nm}(0.002 \mu \mathrm{m})$ from vapours such as sulphuric acid, organic vapours and nitrogen-containing bases. This can happen both during regional scale atmospheric new particle formation events and at a smaller scale, for example in combustion plumes, when vapours suddenly cool immediately upon their introduction to ambient air. In this work, the latter, particles formed during the initial cooling and rapid dilution after the vapours are emitted to atmosphere, are also considered primary particles in addition to those emitted directly in particle phase. Somewhat larger UFP particles, still in nucleation mode size range, are formed, e.g. in new particle formation processes occurring already before the combustion plume is emitted to the atmosphere and thus producing cores for cooling vapours to condense on (e.g. Rönkkö et al., 2007; Lähde et al., 2010). Black carbon, i.e. soot particles, formed in flames by agglomeration of cyclic carbon molecules and emitted often with a coating of condensed organic or inor- ganic vapours, are also partly in UFP size range $(<0.1 \mu \mathrm{m})$, but their size distribution extends to FP size range. FP are emitted also from other thermal sources, as well as from mechanical sources like dust resuspension, wear, fragmentation and suspension of biological matter. Fine particles are also formed from ultrafine particles by growth via atmospheric condensation of anthropogenic and biogenic organic compounds, sulphuric acid and nitrates on the particle's surface. Biogenic condensation growth of UFP is a significant contributor to fine particle number concentrations. It has been estimated that out of the total number of fine particles over the European continent, roughly $50 \%$ have been formed through growth of UFP by condensed biogenic organic vapours (Paasonen et al., 2013a).

The legislation on aerosol emissions and concentrations is based on particle mass, mainly due to the well-established knowledge on the correlation of $\mathrm{PM}_{2.5}$ and adverse health effects (Pope et al., 2002, 2009). However, the increasing evidence of the adverse health impacts of UFP, as well as the unresolved significant uncertainties on the aerosol-climate effects due to aerosol-cloud interactions, require more attention to the anthropogenic particle number emissions. The mass emissions cannot be directly converted to number emissions, because the ratio of mass and number emissions depends greatly on the size distribution of emitted particles. Additionally, because the main removal mechanism of the smallest of UFP in the atmosphere is their coagulation to larger particles (e.g. Kerminen et al., 2001), a decrease in $\mathrm{PM}_{2.5}$ emissions might even increase PN concentrations (Pirjola et al., 2015).

In global climate modelling work, the number emissions are typically extracted from mass emissions applying constant factors and size distributions for different highly aggregated source sectors (e.g., traffic, biomass burning, power generation, etc.). This approach can be used for producing future scenarios also for number emissions and their size distributions. An example of such an approach is the widely applied emission database, the AeroCom project (Dentener et al., 2006), in which the size distributions are fixed and averaged over a wide variety of different sources under the main sectors. Thus, the changes in technology and fuels are reflected in number emissions through a linear dependence between mass and number emissions, since the size distribution is assumed to remain the same. On the other hand, the aerosol number emissions and their size distributions with information on different emission abatement techniques have been studied lately resulting in a size-resolved European particle number emission inventory (Denier van der Gon et al., 2009, 2010, 2013, 2014; Kulmala et al., 2011) which has been tested in several UFP modelling exercises (e.g. Fountoukis et al., 2012; Kukkonen et al., 2016). Emission inventories are not directly applicable for estimating the future trends in emissions as they are based on available statistics, which generally lag several years behind the present day. However, in combination with projections of activity data and assump- 


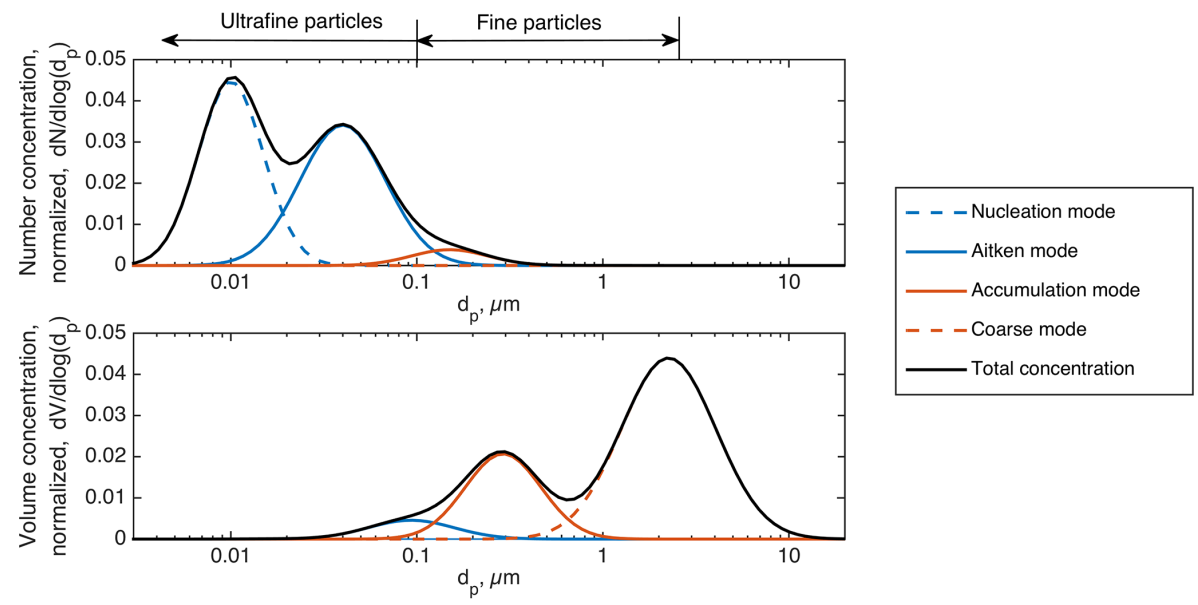

Figure 1. Number size distribution of a fictional and simplified particle population within the planetary boundary layer with four lognormal particle size modes (upper panel) and the same population represented with mass size distribution (lower panel). Note that in the literature it is common to use the term "fine particles" (FP) when referring to all particles with diameters below $2.5 \mu \mathrm{m}$, including ultrafine particle (UFP) size range. However, in this article we exclude UFP size range from FP.

tions about penetration of control technologies a present-day inventory can form a starting point for projected future emissions.

Here we describe and present the first results of the implementation of aerosol number emission factors and their size distribution to the global emission scenario model GAINS (Greenhouse Gas - Air Pollution Interactions and Synergies; Cofala et al., 2007; Amann et al., 2011) developed at IIASA (International Institute for Applied Systems Analysis, Austria). The implementation of these factors in the GAINS-Europe model, describing only European emissions, was published in an IIASA report (Paasonen et al., 2013b). We also estimate emissions and size distribution of the black carbon containing particles and the black carbon cores in them.

The GAINS model has a more detailed technological structure than many available inventories and thus we are able to estimate the implications of future abatement technology changes on number emissions and size distributions. GAINS has been previously applied to analyse the effect of emission abatement policies and other factors affecting the emissions in terms of traditional air pollutants, including particle mass and greenhouse gases. The GAINS model has supported the Commission in the review of the Thematic Strategy on Air Pollution (TSAP; European Commission, 2005) and its related legal instruments on ambient air quality and national emission ceilings through modelling of emission baselines and scenarios for different policy options and their related impacts (Amann et al., 2013). With the implementation of aerosol number emission factors to GAINS, the future particle number emissions can be estimated in a consistent manner with other air pollutants and greenhouse gases. This information can be used for estimating the effects of emission regulations and technological improvements on the health ef- fects of ultrafine particles and on aerosol-climate effects in future decades, as well as for planning particle number emission measurements for the sources that are so far not well enough reported.

\section{Methods}

\subsection{The GAINS model}

The GAINS model (Amann et al., 2011) is an integrated assessment model that brings together information on the sources and impacts of air pollutant and greenhouse gas emissions and their interactions. GAINS combines data on economic development, the structure, control potential and costs of emission sources, the formation and dispersion of pollutants in the atmosphere and an assessment of environmental impacts of pollution.

GAINS assesses all the main air pollutants and greenhouse gases $\left(\mathrm{SO}_{2}, \mathrm{NO}_{x}, \mathrm{PM}, \mathrm{NMVOC}, \mathrm{NH}_{3}, \mathrm{CO}_{2}, \mathrm{CH}_{4}, \mathrm{~N}_{2} \mathrm{O}, \mathrm{F}\right.$ gases) with more than 1000 measures to control the emissions to the atmosphere for each of its nearly 170 regions. Applying built in source-receptor relationships (developed in collaboration with atmospheric groups running chemical transport models for a given domain), GAINS identifies the least-cost balance of emission control measures across pollutants, economic sectors and countries that meet userspecified air quality and climate targets.

In GAINS, emissions from different sources are calculated with three basic input parameters (Klimont et al., 2002):

- Annual activity levels $(A)$ in a given sector, corresponding to certain fuels (e.g., fuel wood used (burned) per year in domestic single house boilers), 
- Shares $(X)$ of abatement technologies applied to fuel consumption of the activity (e.g., improved boilers with accumulation tank, pellet boilers, boilers with electrostatic precipitator, etc.) such that $\sum X=1$,

- Emission factors (EF) for each sector-fuel-technology -combination (emissions per unit of activity).

Activity levels $A$ in GAINS are based on the information from international statistics available from International Energy Agency (IEA), Organisation for Economic Cooperation and Development (OECD), United Nations (UN) and Food and Agriculture Organization of the United Nations (FAO), Eurostat, and national statistics. The shares of control technologies $X$ are derived from published information on national and international legislation, for example for transport sector from diesel.net, discussions with the national experts, and scientific publications where similar assessment has been performed. The emission factors $\mathrm{EF}$ are determined from the scientific publications and measurement databases.

The yearly emissions $E$ in region $i$ are calculated as

$E_{i}=\sum_{i j k m} E_{i j k m}=\sum_{i j k m} A_{i j k m} X_{i j k m} \mathrm{EF}_{i j k m}$,

where the indices $j$ refer to source sector, $k$ to fuel and $m$ to abatement technology.

Within GAINS, future emissions are estimated for different scenarios of anthropogenic activities (e.g., energy use), for which shares $X$ of different technology levels for all emission sources are assumed. Here we present results based on the Current Legislation (CLE) baseline scenario created in the ECLIPSE project, specifically version 5 of this scenario (ETP_CLE_v5, Klimont et al., 2016a, b; Stohl et al., 2015).

\subsection{Particle number emission factors and size distributions}

The determination of emission factors (EFPN) for particle number (PN) emissions and particle size distributions (PSD) is based on the European particle number emission inventory developed by TNO (Netherlands Organisation for Applied Scientific Research; Denier van der Gon et al., 2009, 2010) during the EUCAARI project (Kulmala et al., 2011). The emission factors and emissions described both in TNO work and in this study include both the particles emitted to atmosphere directly in particle phase, as well as those formed from vapours immediately after the emission during the rapid cooling and dilution of the exhausts. We consider here particles of both these types as primary particles. The uncertainties related to the emission factors in terms of particles formed immediately after the emissions are discussed in Sect. 4.1.

Particle size distributions present the size segregation of the number emissions into size classes, i.e. the proportions $P_{n}$ of the total number of emitted particles in each size sector $n$. Thus, the emission factor for a single size class $n$ is written as

$\mathrm{EF}_{\mathrm{PN}, n}=P_{n} \mathrm{EF}_{\mathrm{PN}}$

and the $\Sigma P_{n}=1$. Values for the proportions $P_{n}$ are calculated from modal presentations of PSDs, consisting of one to three lognormal modes. The diameter ranges of the size classes applied in the GAINS emissions are shown in Table 1 .

$\mathrm{EF}_{\mathrm{PN}} \mathrm{s}$ were determined through two alternative ways. For some source sectors, including traffic and domestic combustion, both $\mathrm{EF}_{\mathrm{PN}} \mathrm{s}$ and PSDs were determined from the literature directly (these are called hereafter as direct emission factors). For other source sectors, $\mathrm{EF}_{\mathrm{PN} S}$ were determined based on $\mathrm{PM}_{1}$ mass emission factors $\left(\mathrm{EF}_{\mathrm{PM} 1}\right)$ from an earlier version of the GAINS model (Kupiainen and Klimont, 2007). However, deriving an $\mathrm{EF}_{\mathrm{PN}}$ directly from the $\mathrm{EF}_{\mathrm{PM} 1}$ would make the $\mathrm{EF}_{\mathrm{PN}}$ very sensitive to the estimated number of close to $1 \mu \mathrm{m}$ particles, since their mass is significantly larger in comparison to the mass of those with diameter below or around $100 \mathrm{~nm}$. Thus, emission factors for PM in the size range $10-300 \mathrm{~nm}\left(\mathrm{EF}_{\mathrm{PM} 0.3}\right)$ were first derived from $\mathrm{EF}_{\mathrm{PM} 1}$ based on literature on emission mass size distributions and particle densities (Denier van der Gon et al., 2009, 2010; Kulmala et al., 2011). Then, by applying the particle number size distributions from the literature, the $\mathrm{EF}_{\mathrm{PN}} \mathrm{s}$ consistent with $\mathrm{EF}_{\mathrm{PM} 0.3}$ were resolved. The latter type of emission factors is called PM-based emission factors, hereafter.

In our analysis, we employ for many source sectors the emission factors and size distributions provided in the TNO studies (Denier van der Gon et al., 2009, 2010). However, for sources that are most important for particle numbers, such as road transport and wood combustion in the domestic sector, we developed new emission factors and size distributions in order to better fit in the GAINS model, especially in terms of the emission abatement technologies within it. The modifications to the TNO study are described below.

We extended the PSDs in GAINS to cover sizes from electrical mobility diameter $\left(d_{\mathrm{M}}\right)$ of $3 \mathrm{~nm}$ up to aerodynamic diameter $\left(d_{\mathrm{A}}\right)$ of $1 \mu \mathrm{m}$ (see Table 1 ), whereas the particle size range in the TNO study was from $d_{\mathrm{M}}=10 \mathrm{~nm}$ to $d_{\mathrm{A}}=$ $300 \mathrm{~nm}$. The size range was extended to larger sizes in order to allow for comparison between the emission factors for particle number and $\mathrm{PM}_{1}$ mass, the latter being determined as the total mass of particles with $d_{\mathrm{A}} \leq 1 \mu \mathrm{m}$. Additionally, even though the number share of particles larger than $300 \mathrm{~nm}$ in all emitted particles is negligible, large particles are important in some source sectors. The extension towards smaller diameters was made to provide the whole particle size range for climate model calculations, but it should be noted that no modes with diameters below $10 \mathrm{~nm}$ were introduced. These extensions of the particle size ranges required recalculation of the $\mathrm{EF}_{\mathrm{PN}} \mathrm{s}$ for source sectors that were originally based on $\mathrm{PM}_{0.3}$ emission factors, with the formula 
Table 1. The diameter ranges of particles in the size classes applied for PN emissions. Diameters are electrical mobility diameters, except for * aerodynamic diameter (see text).

\begin{tabular}{lrrrrrrrrr}
\hline Size class, $n$ & 1 & 2 & 3 & 4 & 5 & 6 & 7 & 8 & 9 \\
\hline Minimum $d_{\mathrm{p}}(\mathrm{nm})$ & 3 & 10 & 20 & 30 & 50 & 70 & 100 & 200 & 400 \\
Maximum $d_{\mathrm{p}}(\mathrm{nm})$ & 10 & 20 & 30 & 50 & 70 & 100 & 200 & 400 & $1000^{*}$ \\
\hline
\end{tabular}

\subsection{Black carbon size distribution estimates}

$\mathrm{EF}_{\mathrm{PN}}=\frac{1}{\rho \sum_{n} P_{n} \frac{\pi}{6} d_{n}^{3}} R\left(\mathrm{PM}_{0.3} / \mathrm{PM}_{1}\right) \mathrm{EF}_{\mathrm{PM} 1}$,

where $\rho$ is the estimated density of the emitted particles, $P_{n}$ is the proportion of particles in size class $n$ out of the total number of emitted particles, $d_{n}$ is the geometric mean diameter of the particles in size class $n$, and $R\left(\mathrm{PM}_{0.3} / \mathrm{PM}_{1}\right)$ describes the ratio of $\mathrm{PM}_{0.3}$ and $\mathrm{PM}_{1}$-masses. The values for $\rho, R\left(\mathrm{PM}_{0.3} / \mathrm{PM}_{1}\right)$ and PSDs were taken from the TNO analysis, with the exception of the PSDs mentioned below.

New PSDs were introduced for road transport sources with the highest activities (diesel heavy-duty trucks and busses, both diesel and gasoline light-duty trucks and passenger cars), based on the EU FP7 project TRANSPHORM database (Vouitsis et al., 2013). Additionally, the emission factors for diesel-fuelled road transport were made dependent on the fuel sulphur content (FSC), based on vehiclespecific FSC dependent emission factors provided by the Laboratory of Applied Thermodynamics at the Aristotle University of Thessaloniki, which is responsible also for the TRANSPHORM database. Also $\mathrm{EF}_{\mathrm{PN}} \mathrm{S}$ and PSDs for domestic wood combustion (including pellet burning and medium size district heating boilers) and for shipping emissions (fuel sulphur content-dependent $\mathrm{EF}_{\mathrm{PN}} \mathrm{S}$ and PSDs) were updated (domestic sector: Gaegauf et al., 2001; Hedberg et al., 2002; Johansson et al., 2004; Johansson et al., 2008; Kinsey et al., 2009; Lack et al., 2009; Lamberg et al., 2011; Bäfver et al., 2011; Boman et al., 2011; Pettersson et al., 2011; Chandrasekaran et al., 2011; shipping: Hobbs et al., 2000; Sinha et al., 2003; Petzold et al., 2008; Murphy et al., 2009; Moldanova et al., 2011; Diesch et al., 2013), as well as for two-stroke vehicles in road transport (Ntziachristos et al., 2005; Etissa et al., 2008). A new PSD was introduced also for flaring in gas and oil industry (Canteenwalla et al., 2006). The $\mathrm{EF}_{\mathrm{PN}}$ for tyre wear, previously based on $\mathrm{EF}_{\mathrm{PM} 0.3}$, was replaced with a direct PN emission factor (Dahl et al., 2006).

We note that many of the measured $\mathrm{EF}_{\mathrm{PN}} \mathrm{s}$ and PSDs are not representing the particles which either have diameters below $10 \mathrm{~nm}$ or are volatile in temperatures above typical atmospheric temperatures. Thus, it is likely that in the current set of emission factors the nucleation mode particles $\left(d_{\mathrm{p}}<20 \mathrm{~nm}\right)$, which are formed from vapour molecules during their initial cooling when introduced to the atmosphere, is largely overlooked.
In addition to determining the emission factors and size distributions for total particle number emissions, we also made estimates for black carbon emission size distributions. Two different size distributions were determined, one for the whole particles in black carbon mode $\left(\mathrm{BC}_{\text {mode }}\right)$, which considers both the black carbon cores and the condensed material on them, and one for the black carbon cores of these particles $\left(\mathrm{BC}_{\text {core }}\right)$.

The division of emitted particles to black carbon containing particles and other particles was made depending on the source of particles and the geometric mean diameters of the number size modes of the emitted particles. Naturally, only the combustion-related sources were considered to produce black carbon. Of the combustion sources, only the modes with geometric mean diameters (GMD) equal to or above $50 \mathrm{~nm}$ were taken as black carbon modes. This rough estimate for a minimum GMD was chosen, because the agglomeration in $\mathrm{BC}$ formation produces a roughly lognormal mode and we assumed that it would not form particles in the smallest size ranges of the modes with GMD below $50 \mathrm{~nm}$ (Sorensen and Feke, 1996; Kholghy et al., 2013). This assumption seems reasonable for diesel-fuelled vehicles, but might not be valid for gasoline-fuelled vehicles (Liggio et al., 2012). However, as the global emissions from diesel-fuelled vehicles are found to dominate the transport emissions, we will leave the further improvements on defining the black carbon modes to future studies.

The size distribution of the black carbon cores in the black carbon containing particles was calculated with two combinations of assumptions. In both it was assumed that all the BC mode particles (defined as above) have a black carbon core and that both the core and the particle are spherical. The difference was that in one calculation we assumed that there is only organic carbon (OC) condensed on the $\mathrm{BC}$ core, and in the other calculation that all $\mathrm{PM}_{1}$ additional to $\mathrm{BC}$ is condensed onto this core. The shares of $\mathrm{BC}, \mathrm{OC}$ and other $\mathrm{PM}_{1}$ were defined with mass emission factors for $\mathrm{BC}$, $\mathrm{OC}$ and $\mathrm{PM}_{1}$ in GAINS. A further, simplified assumption was made that the shares of $\mathrm{BC}$ and $\mathrm{OC}$ (or $\mathrm{BC}$ and other $\mathrm{PM}_{1}$, when the latter is considered as condensed matter) were the same in all $\mathrm{BC}$ containing particles regardless of their size. This might slightly overestimate the share of condensed matter in $\mathrm{BC}$ mode for the sources in which there is significant non-BC mode (with GMD $<50 \mathrm{~nm}$ ). The geometric mean diameters 

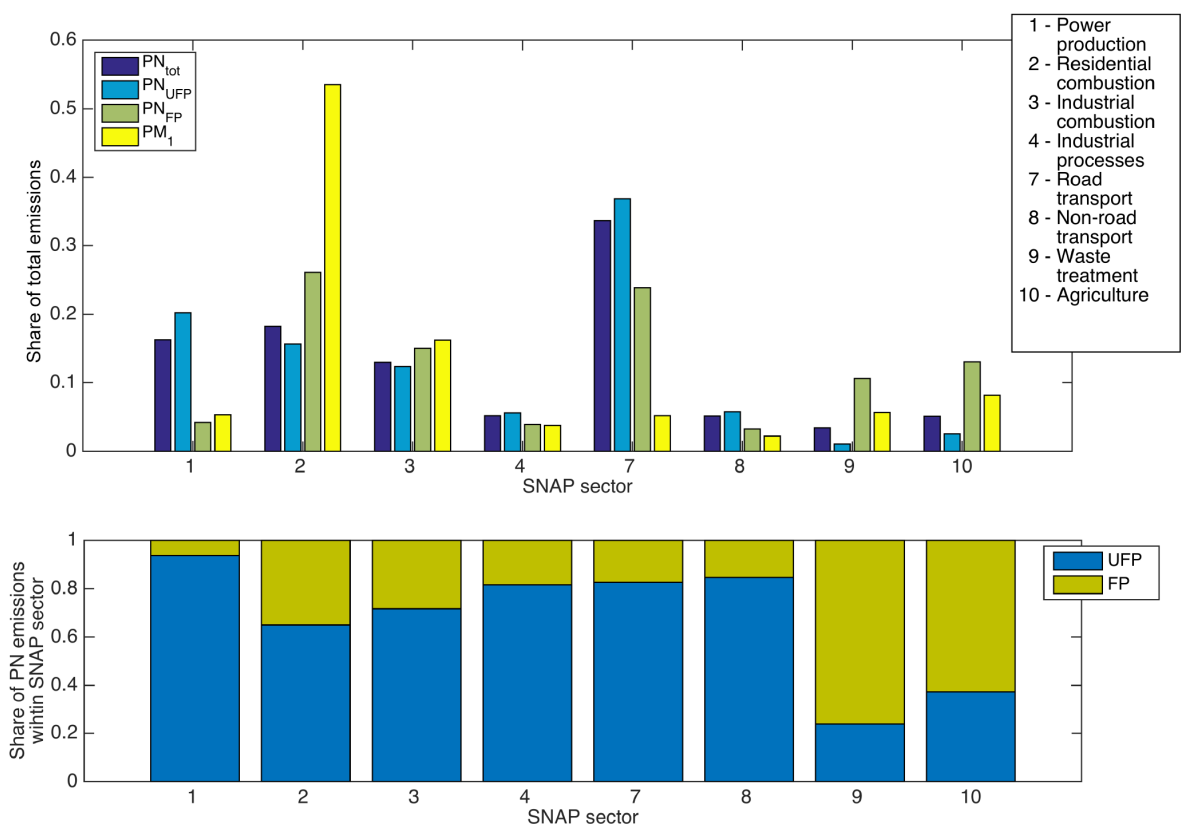

Figure 2. Upper panel: shares of different source sectors in number emissions of all ( $\left.\mathrm{PN}_{\text {tot }}\right)$, ultrafine (PNUFP) and fine (PNFP) particles and in aerosol mass emissions of particles with diameters below $1 \mu \mathrm{m}\left(\mathrm{PM}_{1}\right)$ for 2010. Lower panel: shares of UFP and FP in PN emissions for each SNAP-sector.

of the BC-cores were derived simply from these assumptions based on the mass emission factors and $\mathrm{BC}$-mode geometric mean diameter $\mathrm{GMD}_{\mathrm{BCmode}}$. For the case of only OC condensing on the particles the geometric mean diameter of the core was

$\mathrm{GMD}_{\mathrm{BCcore} 1}=\mathrm{GMD}_{\mathrm{BCmode}} \times\left(\frac{\mathrm{EF}_{\mathrm{BC}}}{\mathrm{EF}_{\mathrm{BC}}+\mathrm{EF}_{\mathrm{OC}}}\right)^{1 / 3}$

and, for the case of all $\mathrm{PM}_{1}$, except for $\mathrm{BC}$, assumed to be formed through condensation

$\mathrm{GMD}_{\mathrm{BC} \text { core } 2}=\mathrm{GMD}_{\mathrm{BCmode}} \times\left(\frac{\mathrm{EF}_{\mathrm{BC}}}{\mathrm{EF}_{\mathrm{PM} 1}}\right)^{1 / 3}$.

\subsection{Uncertainties}

In the results presented in Sect. 3 we have not depicted error bars or shown other illustration of uncertainties. The major sources of uncertainties are mentioned in text within Sect. 3, and discussed in more detail in Sect. 4.

\section{Results}

The calculated aerosol number emissions in 2010 were dominated by ultrafine particles, which contributed to total PN emissions by about $80 \%$. However, emissions from different sources varied in terms of particle size, which is presented in the lower panel of Fig. 2 as the division of number emissions to UFP and FP size ranges in each source sector. The upper panel of Fig. 2 shows the shares of different sources in the global anthropogenic continental total particle number emissions, number emissions of ultrafine particles (UFP, $\left.d_{\mathrm{p}}<0.1 \mu \mathrm{m}\right)$ and FP $\left(d_{\mathrm{p}}>0.1 \mu \mathrm{m}\right)$, as well as mass emissions of particles with $d_{\mathrm{p}}<1 \mu \mathrm{m}\left(\mathrm{PM}_{1}\right)$, all for year 2010 . The main source of UFP was road transport, corresponding to $40 \%$ of UFP emissions and thus being the largest contributor to total aerosol particle number emissions. Power production also contributed to the UFP emissions with $20 \%$ share, mainly due to emissions from coke production, and residential combustion with $17 \%$ share. In FP size range, the shares of residential combustion and road transport were quite similar, roughly $30 \%$ each, whereas the mass emissions of particles with diameters below $1 \mu \mathrm{m}\left(\mathrm{PM}_{1}\right)$ were dominated by residential combustion ( $>50 \%$ ). These differences indicate the need for assessing the size-segregated number emissions of aerosols in addition to mass emissions, in order to better understand their role in atmospheric processes as well as their climate and health effects. It is also important to notice that there is most probably more difference between number emissions and $\mathrm{PM}_{2.5}$ mass emissions (which is often the regulated and monitored quantity) than between number emissions and $\mathrm{PM}_{1}$ emissions.

\subsection{Overall emissions in different parts of the world}

Total annual aerosol number emissions and their current trend for different continents, with Eurasia divided to major countries and the rest of Europe and Asia, are depicted in Fig. 3. The future trend is based on the current legisla- 


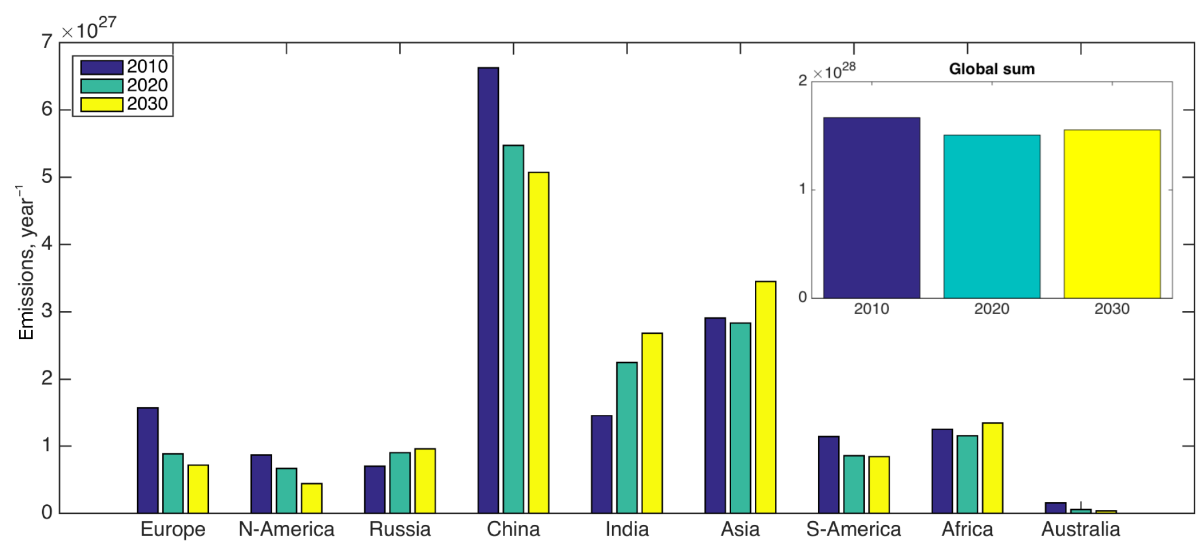

Figure 3. Evolution of continental anthropogenic particle number emissions from 2010 to 2030 according to the current legislation scenario in different parts of the world and the whole world.

tion baseline scenario (ETP_CLE_v5, Klimont et al., 2016a, b; Stohl et al., 2015). In 2010, China had by far the major PN emissions with $40 \%$ estimated share of the global emissions, followed by Asia (excl. China, India and Russia) and Europe (excl. Russia). However, the actions determined in the current legislation scenario resulted in a decrease in emissions in China, as well as in Europe, North and South America. On the contrary, especially in India, but also in Russia, Asia and Africa, the increase in activities seems to offset the benefits of more stringent legislation. The global sum of continental anthropogenic emissions is expected to decrease from 2010 to 2020 by roughly $15 \%$ (from $1.5 \times 10^{28}$ to $1.3 \times 10^{28}$ year $^{-1}$ ), but remain quite constant from 2020 to 2030 .

\subsection{Main aerosol number sources in 2010 and expected changes until 2030}

The aerosol number emissions were dominated by road transport in Europe, North and South America, Asia and Australia in 2010 (blue bars in Fig. 4). In Africa and India the emissions from residential combustion were the main sources together with road transport, whereas in Russia, the emissions from industrial processes, road transport and non-road transport were on a similar level. In China, the major source sector for particle number emissions was power production, followed by residential and industrial combustion emissions. In general, it should be noted that with the current set of emission factors the uncertainties are lesser in North America and Europe, where most of the applied emission factor measurements are made (more in Sect. 4).

In the following subsections (3.2.1-3.2.5), we discuss separately the major sources of aerosol number emissions and their predicted changes from 2010 to 2030 . In these subsections, the percentages given for the shares of different sources refer to emissions in 2010, if not stated otherwise.

\subsubsection{Power production emissions}

The dominance of the power production emissions in China was caused by the emissions from coke production, which accounted for $95 \%$ of Chinese power production emissions in 2010. The significant contributions of power production to emissions in Russia and India were caused by coke production (88 and $79 \%$, respectively).

The coke production emissions in China were estimated to decrease over $50 \%$ from 2010 to 2020, whereas in India and Russia coke production emissions were predicted to increase by 200 and $70 \%$, respectively. The decrease in Chinese emissions resulted mainly from large-scale replacement and closure of small inefficient coke ovens with modern installations, often equipped also with measures to capture and remove dust emissions, which offsets the $20 \%$ increase in activity level. For India and Russia, changes in abatement technology shares did not take place in the applied CLE scenario, and thus the changes were due to increased activity levels only.

However, the coke production emissions are subject to significant uncertainties. Additionally, the emission factors applied for (coal-fired) power plants are not dependent on the sulphur removal technologies or sulphur contents of the fuels, but only on particle removal technologies. The applied power plant emission factors are designed for power plants in Europe, where sulphur removal technologies are in place. This may cause significant underestimation in the emission estimates for power plants using high sulphur fuels (for other power production sources than coke production) in many parts of the world, where a significant fraction of the power plants are not equipped with such technologies. Thus, the presented results on power production emissions have to be considered as preliminary estimates. It seems obvious that coke production causes at least a significant part of the aerosol number emissions in question, but the future trends especially in China are very uncertain, depending on 

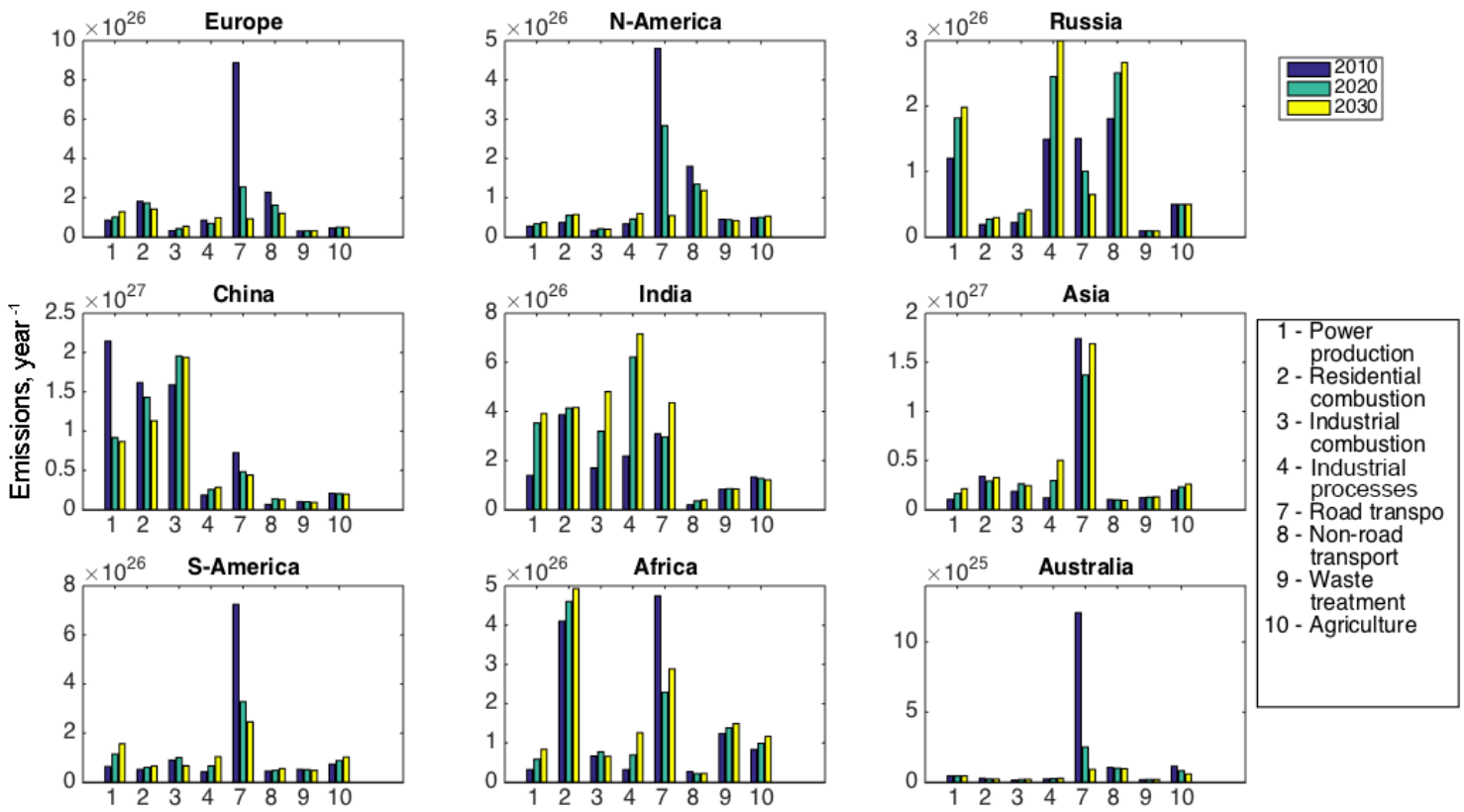

Figure 4. Contributions of different source sectors to particle number emissions in different parts of the world, from 2010 to 2030 . Note the different $y$ axis scales.

the rate of activity level increase and overall emission factor decrease due to improving technology. These uncertainties, also influenced by the general uncertainties related to the representativeness of the PN emission factors for nucleation mode sulphate/sulphuric acid particles, are discussed in more detail in Sect. 4.

\subsubsection{Residential combustion}

Residential combustion was a significant source of particles, especially in China, India and Africa. All these emissions originated mainly from cooking stoves, but used fuels varied. In India, firewood, agricultural residues and coal contributed each by a share of $25 \%$ or more to the residential combustion emissions, and also dung combustion had a share of over $10 \%$. In China $64 \%$ of the emissions originated from coal combustion, roughly $24 \%$ from combustion of agricultural residues and only $7 \%$ from firewood combustion, whereas in Africa $85 \%$ of emissions came from firewood combustion (activity levels for dung combustion are available only for India). The uncertainties related to residential combustion emissions are discussed in Sect. 4.

In India and Africa the residential combustion emissions were expected to increase slightly due to the increase in the activity levels. On the other hand, the emissions from residential combustion in cooking stoves in China were estimated to decrease by $25-30 \%$ per decade due to the reduced coal use in residential sector which results in an overall decrease in residential combustion emissions in China.

\subsubsection{Industrial combustion and processes}

Industrial combustion was estimated to contribute significantly to the total aerosol number emissions in China and India, and the emissions from industrial processes were notable in Russia and India. In China, the industrial combustion emissions were dominated by cast iron production $(75 \%$ of industrial combustion emissions in 2010) and cement production $(10 \%)$, whereas in India the cement production contributed to the industrial combustion emissions by $50 \%$ and cast iron production by less than $10 \%$. It is notable that in India $20 \%$ of industrial combustion emissions were related to biomass fuel combustion.

Of industrial processes, the main source of particle number emissions was estimated to be basic oxygen furnaces, producing over $80 \%$ of Indian and $50 \%$ of Russian emissions. In Russia the other main sources were primary aluminium production (17\%), open hearth furnaces (16\%) and electric arc furnaces $(13 \%)$, the latter contributing by $13 \%$ also to Indian industrial processes emissions.

For all industrial emissions, PM-based emission factors were applied. Thus, the differences in PN emission factors for different emission abatement technologies are not expected to be fully consistent (see Sect. 4).

\subsubsection{Traffic emissions}

The emissions from traffic were the major source of aerosol particles in most parts of the world in 2010. This was the case especially in Western countries and Asia excluding China, India and Russia. Interestingly, even though the total con- 
sumption of fuels in road traffic was highest in Northern America (42 $000 \mathrm{PJ}_{\text {year }}{ }^{-1}$ compared to $31000 \mathrm{PJ}_{\text {year }}{ }^{-1}$ in Asia and $27000 \mathrm{PJ}_{\text {year }}{ }^{-1}$ in Europe) the calculated emissions were the highest in Asia and the lowest in North America. The low emissions in North America were due to much smaller percentage of diesel vehicles than in Europe, whereas the high emissions in Asia were due to (i) the significant share of (diesel) fuel having higher sulphur content than in Europe and North America, and (ii) the smaller proportion of vehicles with new emission abatement technologies.

Based on the measurements collected by Vouitsis et al. (2013), applied for PN emission factors in the GAINS model, the tightening regulation on particle mass emissions decreased drastically the number emissions, as well. This leads to a major decrease in European, North American and Australian emissions from 2010 to 2030, as can be seen in Figs. 3 and 4. Additionally, traffic emissions are the only source of particulate matter, for which also number emissions have been regulated. The new diesel vehicles under EURO VI-technology are limited not to have higher number emissions than $6 \times 10^{11} \mathrm{~km}^{-1}$ for passenger cars (the same limit should be applied also for gasoline vehicles after 2017) and $6-8 \times 10^{11} \mathrm{kWh}^{-1}$ for heavy-duty vehicles. However, these limits are set only for solid particles larger than $23 \mathrm{~nm}$. In practice, this means that only particles with black carbon core are taken into account, since the secondary particles are not considered as solid (they evaporate when the sample is heated) and the nucleation mode particles with a non-volatile core (Rönkkö et al., 2007; Lähde et al., 2010) have diameters well below $23 \mathrm{~nm}$ after evaporation of condensed matter. Thus, the particle number emission limits mentioned above are in principle reached already when older diesel vehicles are equipped with a diesel particle filter (DPF) (Samaras et al., 2005).

In addition to the emission abatement technologies and fuel type (here in principle gasoline vs. diesel, since the global shares of gas- or ethanol-fuelled vehicles are very small), the particle number emissions from traffic were highly sensitive to fuel sulphur content (FSC). This effect is demonstrated in Table 2, where we present the relative change in road transport PN emissions arising from the assumption of replacing all the diesel fuel with ultra low FSC diesel, such as that demanded by legislation, e.g. in the EU and US. Table 2 shows how much the emissions would decrease, in comparison to the actual CLE scenario, if all the consumed diesel fuel was replaced with ultra-low FSC diesel. In Europe, there are some non-EU countries for which, in the CLE scenario, the share of higher FSC diesel remains constant until 2030. Since the total European road traffic emissions are decreasing significantly due to the improving emission abatement technologies, the relative share of emissions from higher FSC diesel increases with time. The table also reveals that the expected decrease in road transport emissions in Australia, Africa, South America and Russia from 2010 to 2020 (see Fig. 4) was caused by decreasing the FSC
Table 2. The relative change in annual road transport PN emissions in comparison to the CLE scenario, if (in addition to the technological advancements described in the CLE scenario) all the diesel fuel (consumed in road transport) is assumed to be replaced with ultralow sulphur content-fuel ( $\mathrm{FSC}=10 \mathrm{ppm})$. The lowest row shows the change in total emissions from all sources. Note that, e.g. in Europe, the impact increases with time, because in the CLE scenario the emissions decrease drastically in most countries, but a small share of high FSC fuel remains present in some (non-EU) countries. Thus, the proportion of the high FSC contribution to total emissions in the CLE scenario increases with time.

\begin{tabular}{lrrr}
\hline & 2010 & 2020 & 2030 \\
\hline Europe & $-5 \%$ & $-8 \%$ & $-24 \%$ \\
N. America & $0 \%$ & $0 \%$ & $0 \%$ \\
Russia & $-48 \%$ & $-1 \%$ & $-3 \%$ \\
China & $-30 \%$ & $-31 \%$ & $-33 \%$ \\
India & $-32 \%$ & $-41 \%$ & $-39 \%$ \\
Asia & $-44 \%$ & $-29 \%$ & $-32 \%$ \\
S. America & $-35 \%$ & $-1 \%$ & $-2 \%$ \\
Africa & $-55 \%$ & $-7 \%$ & $-8 \%$ \\
Australia & $-51 \%$ & $0 \%$ & $0 \%$ \\
\hline Global road traffic & $-32 \%$ & $-21 \%$ & $-27 \%$ \\
\hline Global total & $-11 \%$ & $-5 \%$ & $-6 \%$ \\
\hline
\end{tabular}

in diesel, whereas (according to CLE scenario) in China, India and Asia the share of ultra-low FSC diesel is either not increasing or the effect of its increase is (partly) invalidated by the increasing volume of road transport.

\subsubsection{Other significant sources}

Agriculture has a significant share on particle number emissions in Russia, India and Africa and these emissions were entirely (>99\%) caused by agricultural waste burning (in which slash and burn of forests or other vegetation and forest fires were not included).

In Russia, Europe and Northern America the non-road transport emissions formed a considerable part of the emissions. However, this large non-road transport share was partly due to including the gas pipeline compressor emissions in this sector. These were dominant in Russian non-road transport emissions $(95 \%)$ and constituted a major source also in Northern America (35\%). In Europe the non-road transport emissions came mainly from maritime vessels and the inland waterway transport was also a significant contributor to North American emissions.

One PN source, which might have a notable share in regional emissions but was not included in this study due to lack of data on particle number emission factors, are brick kilns. Brick kilns are a significant source of PM especially in India and other Southeast Asia (Bhat et al., 2014). 

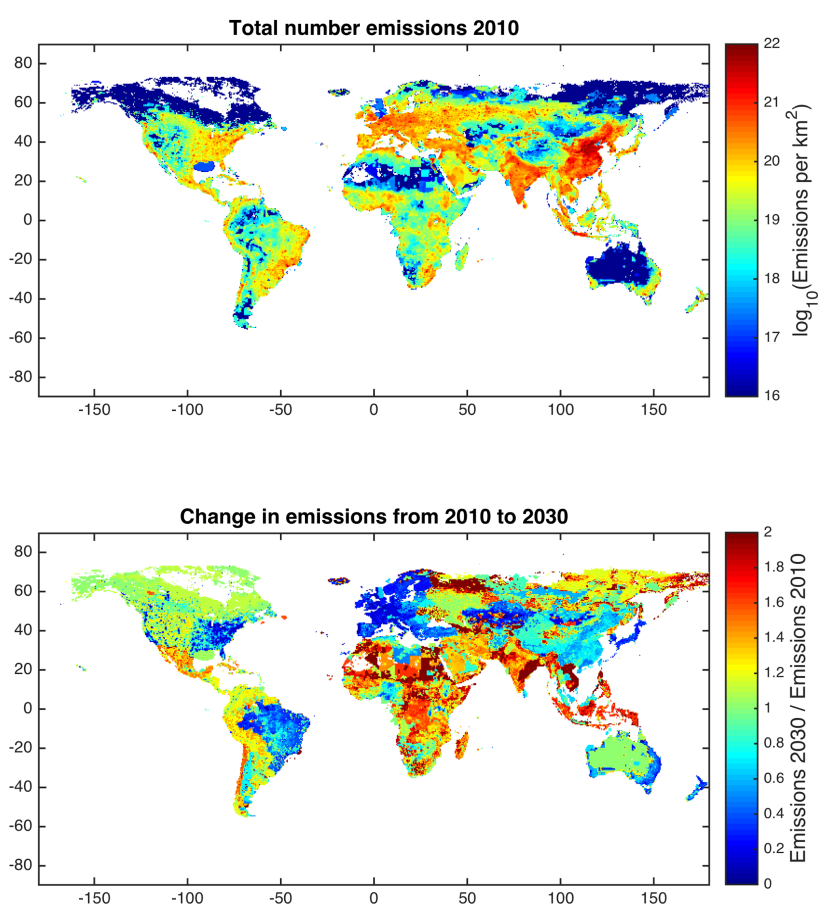

Figure 5. Spatial distribution (in $0.5^{\circ} \times 0.5^{\circ}$ grid) of global continental anthropogenic particle number emissions in units $\mathrm{km}^{-2}$ year $^{-1}$ (upper panel) and predicted relative change in particle number emission from 2010 to 2030 (lower panel). The gridded emissions are available from http://www.iiasa.ac.at/web/home/ research/researchPrograms/air/PN.html.

\subsection{Spatial distribution of emissions}

Aerosol particles are short-lived climate forcers with lifetimes roughly up to a week and the aerosol number size distributions evolve rapidly especially under high concentrations close to the sources. Thus, the regional particle concentrations leading to health and climate effects cannot be defined with emissions described in country or region level, but it is essential to assess the emissions with higher spatial resolution. The gridding of emissions down to $0.5^{\circ} \times 0.5^{\circ}$ resolution, as applied in the GAINS emission model allows for estimating the regional concentrations when combined with air quality or climate models. The gridded particle number emissions presented here can be downloaded from GAINS model website (http://www.iiasa.ac. at/web/home/research/researchPrograms/air/PN.html) with a distribution to different size bins as presented in Sect. 3.4.

In the upper panel of Fig. 5 the gridded global emissions are presented for the year 2010. The gridded emissions ranged in a span of various orders of magnitude (note the logarithmic colour axis in Fig. 5, where the values below $10^{16} \mathrm{~km}^{-2}$ year $^{-1}$ are shown as having the value of $10^{16}$ ). The highest emissions were seen in North-Eastern China, but all the continents had various grid cells with emissions higher than $10^{21} \mathrm{~km}^{-2}$ year $^{-1}$.
In the lower panel of Fig. 5, we have depicted the estimated change in total aerosol particle number emissions from 2010 to 2030 based on the current legislation scenario. The main areas of significant decrease in emissions were Western Europe, Eastern United States, Brazil, Australia, Japan and China, whereas the emissions in Africa, India and the European part of Russia were predicted to increase notably.

\subsection{Emission number size distributions}

The number size distributions of the major source sectors are presented for years 2010 and 2030 in Fig. 6 (upper panels), respectively. Here we divided the emissions to different sectors (e.g. according to the used fuel) than in previous figures in order to present the differences in size distributions and total emissions related to the different fuels. Especially the domestic combustion of coal and biomass resulted in notably different size distribution with peak values in $20-40 \mathrm{~nm}$ and $\sim 100 \mathrm{~nm}$, respectively. The most significant single particle number sources mentioned in Sect. 3.2 (road transport with diesel fuel and coke production) had peak values in sizes from 30 to $50 \mathrm{~nm}$ in diameter. The difference in size distributions from different sources was visible also when assessing the regional emissions (Fig. 6, bottom panels). In 2010, the emissions in Africa and India were dominated with biofuel combustion and agricultural waste burning peaking at diameters close to $100 \mathrm{~nm}$, whereas the other regions showed highest emissions around $40 \mathrm{~nm}$ diameter. However, the estimated increases in Indian power production, industrial and road traffic emissions towards 2030 moved the size distribution to smaller diameters. On the contrary, the notable decrease in Australian road traffic emissions shifted the size distribution to larger sizes, because one of the main sources in 2030 was estimated to be agricultural waste burning.

\section{Black carbon emission size distribution}

The size distributions of black carbon containing particles as well as the size distribution of the black carbon cores for year 2010, calculated with Eq. (4), are presented in Fig. 7. The global black carbon mode particle emissions were dominated with diesel fuel road transportation, but the contributions of domestic biomass combustion and agricultural waste burning were much higher than for the total particle numbers (compare to Fig. 6, upper left panel). The black carbon mode count median diameter varied from 70 to $100 \mathrm{~nm}$. This variation seems to be at least partly due to the amount of vapours condensed on the black carbon cores: the black carbon core size distributions shown in the middle panel of Fig. 7 show more similar count median diameters of roughly $60 \mathrm{~nm}$ for all other sources than industrial combustion and domestic coal combustion. The difference between the assumptions of the composition of the coating of $\mathrm{BC}$ cores, i.e. the choice between coating including only OC (Fig. 7, middle panel) and coating including all $\mathrm{PM}_{1}$ except $\mathrm{BC}$ (figure not shown), 

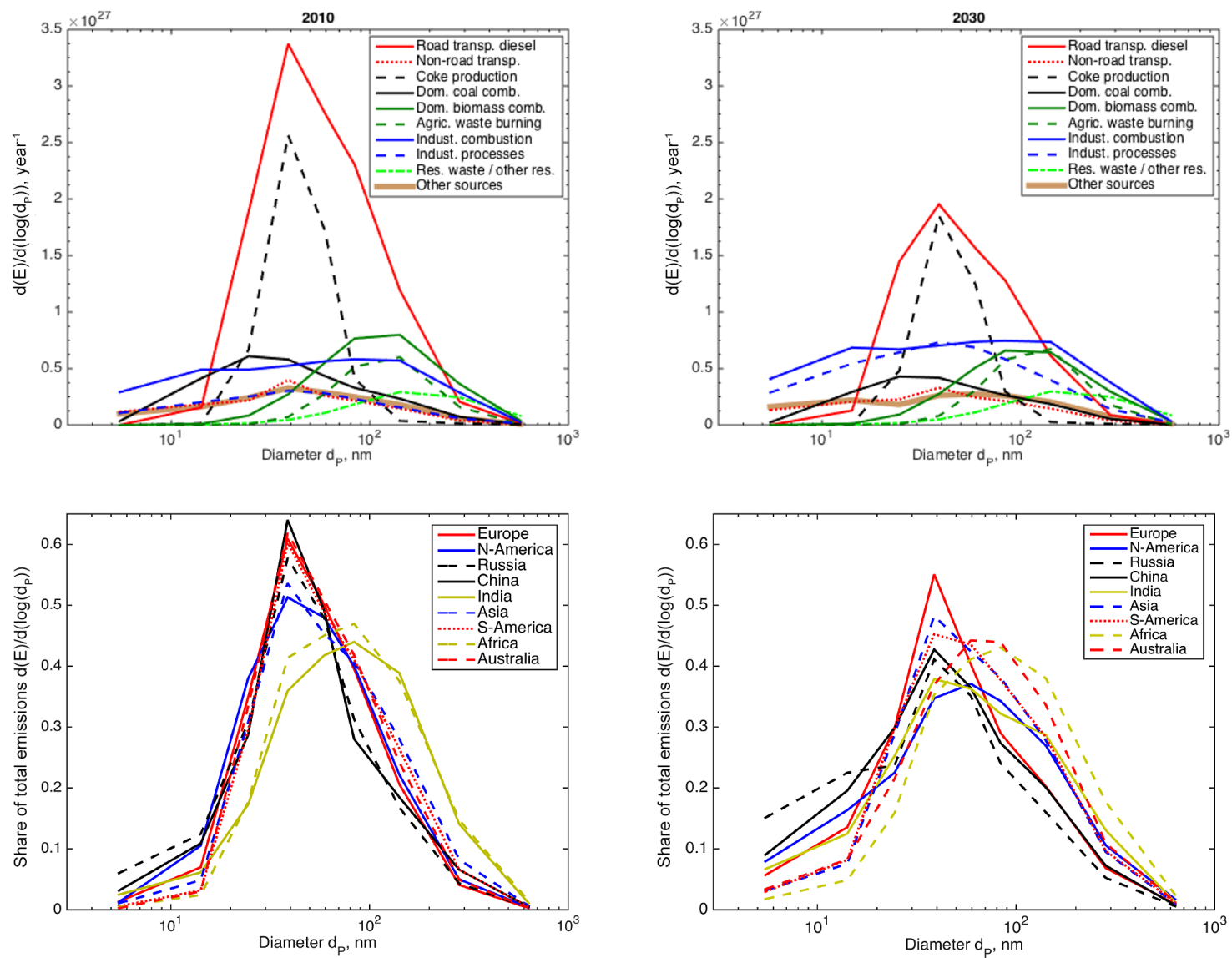

Figure 6. Particle number size distributions of the major global aerosol emission sources (upper panel) and normalized number size distributions for each region (lower panel). The left side figures are for 2010 and the right side ones for 2030.
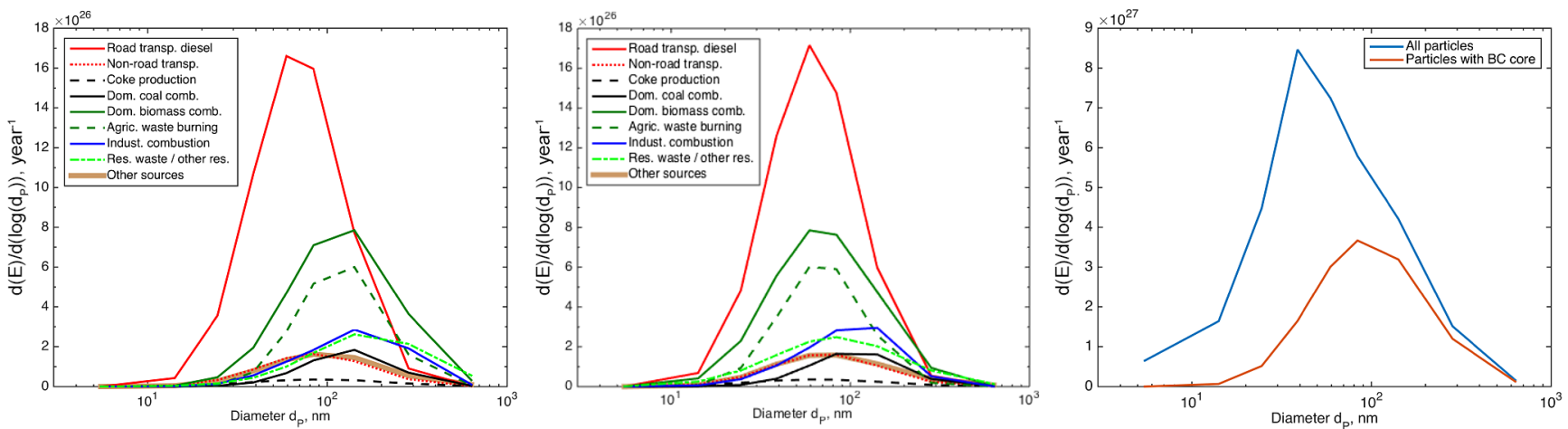

Figure 7. Estimated global number size distributions of the black carbon mode particles (left panel) and of their black carbon cores, assuming only $\mathrm{OC}$ is condensing on the $\mathrm{BC}$ cores (middle panel). Number size distribution of global total PN emissions and emissions of particles with $\mathrm{BC}$ core (right panel). The source categories in the left and middle panels are the same as in Fig. 6.

was significant only in industrial combustion emissions, for which the $\mathrm{BC}$ core mode shifted to much smaller sizes (from $\sim 100$ to $30-40 \mathrm{~nm}$ ) when assuming all $\mathrm{PM}_{1}$ is condensed on $\mathrm{BC}$ cores. This is because in industrial $\mathrm{PM}_{1}$ combustion emissions the shares of $\mathrm{OC}$ and $\mathrm{BC}$ are relatively small. It is to be noted that the method of defining the source-specific
BC modes was approximate, as discussed in Sect. 2.3, and some of the sub- $50 \mathrm{~nm}$ particles here defined as non-BC particles might in reality have a $\mathrm{BC}$ core. Even though this possible underestimation of smaller BC particles is unlikely to concern the diesel emissions (Liggio et al., 2012), which is the main source for BC number emissions, the black carbon 

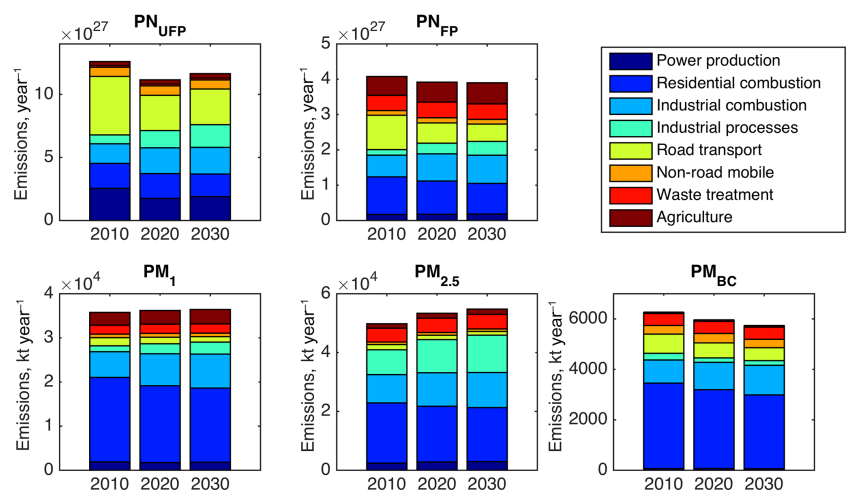

Figure 8. Shares of different source sectors to the future global trends in particle number and mass emissions under current legislation scenario: $\mathrm{PN}$ emissions in ultrafine and fine size ranges and particle mass emissions $\mathrm{PM}_{1}, \mathrm{PM}_{2.5}$ and black carbon.

size distributions from other sources should be assessed in more detail in future.

\subsection{Future trends of emissions in different PN and PM metrics}

The projected future trends of PN emissions (UFP and FP separately) and, for comparison, the mass emissions $\mathrm{PM}_{1}$, $\mathrm{PM}_{2.5}$ and $\mathrm{PM}_{\mathrm{BC}}$ are depicted in Fig. 8 with indicated global contributions of different source sectors. The significant contribution of road traffic to PN emissions caused a decrease from 2010 to 2020 in PN emissions in both UFP and FP size range and the decrease in UFP emissions was enhanced by the decrease in coke production emissions. The decrease in PN emissions was predicted to stop after 2020 due to increase in industrial emissions. This was estimated to cause a slight increase in UFP emissions from 2020 to 2030, but the global FP number emissions seemed to remain constant. Comparison to PM mass emissions revealed that the trends of particle numbers and mass can be very different. The major source in all the depicted mass emissions, $\mathrm{PM}_{1}, \mathrm{PM}_{2.5}$ and $\mathrm{PM}_{\mathrm{BC}}$, was residential combustion, but $\mathrm{PM}_{1}$ and $\mathrm{BC}$ emissions from residential combustion emissions were estimated to decrease more than $\mathrm{PM}_{2.5}$. As the $\mathrm{PM}_{2.5}$ emissions showed the steepest increase in industrial emissions, whereas the BC emissions are affected very little by industrial process emissions, the total $\mathrm{PM}_{2.5}$ emissions showed increase, $\mathrm{PM}_{1}$ remained rather constant and $\mathrm{BC}$ emissions showed clear decrease.

In most parts of the world, the future changes in UFP and FP emissions are predicted to be rather similar (Fig. 9), but the relative change in UFP emissions is typically a bit more pronounced than that of FP particles. However, especially in India the UFP emissions are estimated to increase much more than FP emissions. This is because the emissions from residential combustion and agricultural waste burning, which emit both FP and UFP, are not increasing in India, but the industrial, traffic and coke production emissions, all emitting mainly in UFP size range, are predicted to increase significantly (see Fig. 4). Also in Russia, which is the other area where the number emissions are clearly increasing, the relative increase of UFP emissions is larger than that of FP emissions. In Russia the road traffic emissions are predicted to decrease and the increase in UFP emissions is mainly caused by increases in emissions from industrial processes, coke production and gas pipeline compressors. The mass emissions are depicted also in Fig. 9 for reference, but the reasons for different regional trends are not discussed here.

\section{Uncertainties related to the particle number emission factors}

This article has it main focus on describing the implementation of particle number emission factors in the global GAINS emission scenario model. We present the initial results and demonstrate the future needs for improving the emission factor database. The uncertainties in the particle number emission factors are large and often based on gap-filling. Based on the presented results, further research can be planned and we see these estimates, albeit uncertain, as progress and part of the results.

The uncertainties in the emission factors are due to the following main reasons, (i) the lack of reliably reported measurements for the particle number emission factors and the related size distributions, (ii) geographic unrepresentativeness of the applied emission factors, (iii) application of number emissions factors based on PM mass emission factors (instead of applying a direct number emission factor), and (iv) a lack of representative measurements for fuels with high and/or varying sulphur contents. High sulphur contents give rise to high emission of particles of a very small size $(<10 \mathrm{~nm})$, these numbers can be expected to dominate total $\mathrm{PN}$ emissions in many sources.

The above-listed causes for uncertainties are in many cases linked; e.g. the reason for applying PM-based emission factors for determining number emission factors is due to the lack of available direct number emission factors. They also make the geographic variation of uncertainties very prominent. In Europe and Northern America, the overall uncertainties, even though significant in absolute values, are smaller in comparison to the other continents, both in terms of current and future emissions. This is because most of the emission factor measurements have been conducted in these continents and in both the dominant sources of emissions are road traffic and residential wood combustion, both with well-established direct number emission factor database for different emission abatement technologies. On the contrary, the emission factors for the dominant particle number sources in Asia (including China, India and Russia) are in most cases based on only few (often European or American) studies, and the effect of emission abatement technologies is typically based on $\mathrm{PM}_{1}$ emission factors. Also the pronounced wood combus- 

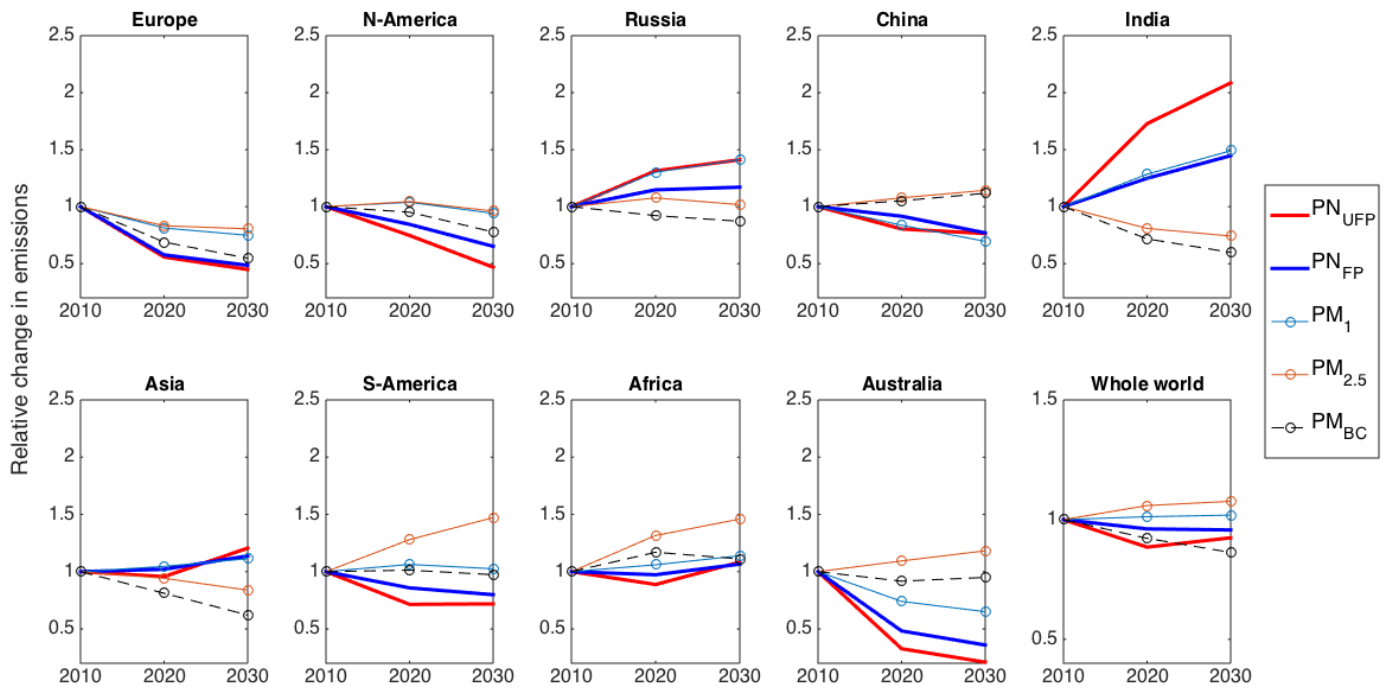

Figure 9. Continental future trends of particle number and mass emissions under current legislation scenario. Emissions are normalized to unity in 2010. Note the different $y$ axis scale in the subplot for the whole world.

tion emissions from cooking in Africa are based on emission factors from (traditional western) heating stoves and are thus rather uncertain.

In the following we discuss shortly the most important individual causes for uncertainties in the results presented in Sect. 3.

\subsection{General causes of uncertainties in PN emission factors}

\section{Applying PM-based emission factors in general}

The emission abatement technologies have typically different removal efficiencies for particles with different diameters. However, when the emission factors for different technologies are determined by simply scaling the emission factor with the corresponding change in PM emission factor, the PSD remains unchanged. This may result in erroneous estimates of $\mathrm{EF}_{\mathrm{PN}}$, e.g. if a source with high emissions of fine particles and condensable vapours is controlled with a removal technology for the fine particles, the formation of ultrafine particles from the vapours may increase due to drastic decrease in the condensation sink for the vapours and coagulation sink for the freshly formed particles.

\section{Effect of sulphur on PSDs and emission factors}

It is well known that sulphuric acid, formed from $\mathrm{SO}_{2}$ after oxidation to $\mathrm{SO}_{3}$, is a key player in atmospheric new particle formation. It has been also shown in many studies that, by increasing the fuel sulphur content, the primary emissions of ultrafine particles are increased (e.g. Rönkkö et al., 2013). However, the nucleation mode particles formed from sulphur (and other condensable vapours) are often not well represented, in some cases not at all, in the PN emission factors and PSDs in the literature. Some instruments applied for the measurements are not able to measure concentrations of particles with diameters below $10 \mathrm{~nm}$, and in some cases the nucleation mode particles are evaporated before they are detected. It can be expected that by making new experiments on the PN emission factors and PSDs with instruments suitable for detection of nucleation mode particles, the overall figure of UFP emissions will alter significantly. It might be also possible to derive semi-empirical estimates of the nucleation mode particle emissions by taking into account the $\mathrm{SO}_{2}$ emissions.

Additional uncertainties related to sulphur emissions arise from the lack of emission factors for different fuel sulphur contents in sources other than road traffic. Especially in coal combustion the emissions can be expected to depend heavily on the coal sulphur content. Also for the road traffic emissions, the uncertainties are considerably higher for higher FSC diesel than for ultra-low FSC diesel or gasoline.

\section{Effects of ambient conditions on emissions}

The numbers and size distributions of emitted particles depend also on the ambient conditions in which they are emitted, e.g. on temperature. The volatility of vapours is strongly dependent on temperature, which naturally causes evaporation when fuel is heated. Some of the vapours that do not effectively condense onto particles and/or form new nucleation mode particles in room temperatures may still be condensable when temperature is lower. This would affect the emissions most probably in the colder parts of the world and especially in winter. Also the particle concentrations prior to emission can be presumed to affect the PN number emissions (at least when the immediate formation of secondary parti- 
cles are considered as PN emission), due to the competition of (emitted) vapour uptake between new particle formation and condensation to pre-existing particles. These kinds of effects are, however, issues for future research and their impact cannot be implemented directly to the GAINS model.

\subsection{Sector-specific causes of uncertainties in PN emission factors}

\section{Coke production}

Emission factor for coke production is based on $\mathrm{PM}_{1}$ emission factors and the conversion from mass to number factor and the particle number size distribution are derived from a publication by Weitkamp et al. (2005), in which the authors study the emissions from a large coke production facility near Pittsburgh, US. Other studies for comparing the number size distribution related to coke production, especially in Asia, are needed for verifying the drastic impacts of coke production to regional aerosol emissions. Furthermore, the effects of emission abatement technologies - such as cyclone, 1- and 2field electrostatic precipitators and high-efficiency dedusters - on the particle size distribution and number emission factor need to be studied.

\section{Residential coal combustion}

Residential coal combustion number emission factors are PM-based and were produced with particle size distributions taken from Bond et al. (2002). Further studies for different coal types, including varying sulphur contents, and stove technologies are needed to better estimate the share of residential coal combustion on the particle number emissions especially in China.

\section{Residential wood combustion in traditional cooking stoves}

The emission factors for the cooking stoves, e.g. in African and Asian countries have been adapted from no-control emission factors for heating stoves, which are mostly based on Northern-European and North American studies. Obtaining emission factors for traditional cooking stoves down to a three stone fire, would give a better picture on the residential combustion emissions especially in Africa. Furthermore, estimating the dung combustion activity levels in countries other than India could alter the overall figure to some extent.

\section{Power plant and industry emissions}

The emission factors for power plants and industry are all PM-based, which causes uncertainties especially when assessing the future emissions with improved technologies. Also the fuel sulphur contents are not taken into account, which increases the uncertainty levels.

\section{On the effects of anthropogenic emissions on particle number concentrations}

In this paper we have presented the first results of global anthropogenic primary particle number emissions from the GAINS model. It is important to note that the future trends presented here should not be interpreted as trends for future particle number concentrations, because the relation between particle number emissions and number concentrations are far from linear. Typically, particle number concentrations vary much less than the emissions, because (i) in the areas of low anthropogenic primary emissions the natural emissions and atmospheric aerosol formation (both in terms of vapours condensing on pre-existing particles and formation of new particles from vapours) play a relatively more important role (Paasonen et al., 2013a) and (ii) the most efficient sink for the smallest of aerosol particles in nucleation mode is their coagulation with larger particles (e.g. Kerminen et al., 2001). Because this coagulation sink of particles correlates in many cases with the number emissions (e.g. in the street canyons both the number concentrations and sink are high, and in general both increase when approaching the emission source), the implementation of the GAINS number emissions to air quality or climate models even with the higher spatial resolution $\left(0.5^{\circ} \times 0.5^{\circ}\right)$ may lead to overestimating the concentrations. In order to better approach the health effects of particle number concentration within cities, it is possible to downscale the GAINS emissions to a street canyon scale with the methods presented by Kiesewetter et al. (2014).

Comparison of the global emission trends of different aerosol concentration metrics (Figs. 8-9) reveals their different predicted trends. The global mass emissions of black carbon aerosol, the main aerosol component causing global warming, are predicted to decrease in the future, whereas the global emissions of cooling aerosols, i.e. mass emissions non-BC aerosol (cooling due to scattering of solar radiation) and the number emissions of FP (acting as cloud condensation nuclei, $\mathrm{CCN}$ ) are predicted to increase or decrease less than BC mass emissions. The predicted changes in BC mass emissions and $\mathrm{PN}$ emissions suggest that, even though the $\mathrm{BC}$ particles can act as $\mathrm{CCN}$ after atmospheric aging (Chen et al., 2010), the overall global decrease in BC mass emissions does not lead to a similar decrease in number emission of FP. However, it should be noted that the climate effects do not follow directly the emissions, especially in the case of cloud droplet formation. There are several processes, which can either overrule or dampen the formation of cloud droplets from emitted FP. Firstly, the UFP from both anthropogenic emissions and atmospheric new particle formation grow to CCN sizes, and this growth often produces much more CCN than primary FP emissions, and secondly, the boundary layer height and dilution also affect the concentration levels resulting from the emissions (Paasonen et al., 2013a). Thirdly, the cloud droplet concentration (at least partly) saturates when $\mathrm{CCN}$ concentrations increase, which lessens the cloud form- 
ing effect of FP emitted in moderately or more polluted areas (e.g. Gultepe and Isaac, 1999).

\section{Conclusions}

The aerosol particle number (PN) emission factors and the related size distributions have been implemented in the global GAINS model. The regional PN emissions are dominated by different sources than the particle mass emissions. In most parts of the world the emissions from diesel-fuelled road vehicles were the major source in 2010. Other significant sources for particle numbers were residential combustion of biofuels and coal (especially in China, India and Africa), coke production (Russia and China), industrial combustion and processes (Russia, China and India) and gas pipeline compressors in Russia. However, the PN emission factors for residential coal combustion, coke production and gas pipeline compressors have high uncertainties, which can be reduced only with further new experimental studies on the emission factors.

According to the current legislation scenario, the PN emissions are expected to decrease significantly by 2030 in Europe, North and South America and Australia (64, 49, 26 and $76 \%$, respectively), mainly because of introduction of diesel particulate filters (DPF) in order to comply with new diesel vehicle legislation; the DPFs cut efficiently both particle mass and number emissions. In Southern America and Australia the decrease in road traffic emissions is also partly due to intended switch to ultra-low sulphur content fuels, which is already the only fuel type in use in North America and most of the European countries. Also in China the total PN emissions are estimated to decrease by $23 \%$ from 2010 to 2030, mainly due to the decreases in coke production and residential coal combustion emissions. However, in India the emissions are increasing by over $80 \%$ from 2010 to 2030, in Russia by $37 \%$ and in the rest of Asia by $19 \%$, whereas in Africa the emissions are estimated to increase only by $7 \%$.

The number size distributions of particles differ significantly depending on the source. In terms of the major number sources, traffic, coke production and residential coal combustion show highest emissions in ultrafine particle (UFP) size range, with diameters between 30 and $50 \mathrm{~nm}$, whereas the residential biofuel combustion and agricultural waste burning, as well as industrial combustion, show peaks with diameters around $100 \mathrm{~nm}$. These differences, naturally, cause variation in the total number size distributions of emitted particles in different parts of the world.

The sizes of emitted particles are important when assessing the impacts of the emitted particles. The globally significant climate impact of particle number concentrations arises from the aerosol-cloud interactions, i.e. the activation of particles with diameters close to or over $100 \mathrm{~nm}$ as cloud droplets. On the other hand, the adverse health effects related to particle number concentration are coupled with UFP concentrations. This, together with the dominance of traffic emissions in this size range and the fact that road traffic is a pollution source very close to our everyday life, justifies the need for better assessment of size-segregated PN emissions also in the population health perspective. Thus, this work provides input for both climate and air quality modelling and makes the evaluation between the effects of the future changes in aerosol number emissions and aerosol mass emissions possible.

However, the work described in this paper is the first implementation of the particle number emissions to an emission scenario model such as GAINS. In order to improve the estimates of current and future PN emissions, more experiments on the PN emission factors and size distributions of the sources indicated in Sect. 4 are crucial, as well as a thorough reassessment of the effects of fuel sulphur content and ambient conditions on the emission.

Acknowledgements. This work was funded by the Academy of Finland through Centre of Excellence (grants no. 1118615 and 272041) and WHITE project (grant no. 286699), European Commission 7th Framework projects ECLIPSE (Project no. 282688), PEGASOS (265148), TRANSPHORM (243406) and "Assessment of hemispheric air pollution on EU air policy" (contract no. 07.0307/2011/605671/SER/C3), the Nordic Top-level Research Initiative (TRI) Cryosphere-Atmosphere Interactions in a Changing Arctic Climate (CRAICC) and the Otto A. Malm foundation. We thank Leonidas Ntziachristos and Ilias Vouitsis at Aristotle University of Thessaloniki (Greece) for help and assistance in applying the emission factors for road transport sector, Qiang Zhang from Tsinghua University (Beijing, China) for the spatial distribution of Chinese power plants for 2000, 2005, and 2010, and the personnel at the Air Quality and Greenhouse Gases program at IIASA for their help, especially Imrich Bertok and Binh Nguyen for making the offline work possible and Chris Heyes for gridding the emission data.

Edited by: R. Krejci

\section{References}

Amann, M., Bertok, I., Borken-Kleefeld, J., Cofala, J., Heyes, C., Höglund-Isaksson, L., Klimont, Z., Nguyen, B., Posch, M., Rafaj, P., Sander, R., Schöpp, W., Wagner, F., and Winiwarter, W.: Cost-effective control of air quality and greenhouse gases in Europe: modeling and policy applications, EMS, 26, 1489-1501, 2011.

Amann, M., Borken-Kleefeld, J., Cofala, J., Hettelingh, J.-P., Heyes, C., Holland, M., Kiesewetter, G., Klimont, Z., Rafaj, P., Paasonen, P., Posch, M., Sander, R., Schoepp, W., Wagner, F., and Winiwarter, W.: Policy Scenarios for the Revision of the Thematic Strategy on Air Pollution, TSAP Report \#10. International Institute for Applied Systems Analysis, Laxenburg, Austria, 2013.

Arneth, A., Unger, N., Kulmala, M., and Andreae, M. O.: Clean the air, heat the planet, Science, 326, 672-673, 2009. 
Bäfver, L. S., Leckner, B., Tullin, C., and Berntsen, M.: Particle emissions from pellets stoves and modern and old-type wood stoves, Biomass Bioenerg., 35, 3648-3655, 2011.

Bhat, M. S., Afeefa, Q. S., Ashok, K. P., and Bashir, A. G.: Brick kiln emissions and its environmental impact: A Review, Journal of Ecology and The Natural Environment, 6, 1-11, 2014.

Boman, C., Pettersson, E., Westerholm, R., Boström, D., and Nordin, A.: Stove Performance and Emission Characteristics in Residential Wood Log and Pellet Combustion, Part 1: Pellet Stoves, Energ. Fuel., 25, 307-314, 2011.

Bond, T. C., Covert, D. S., Kramlich, J. C., Larson, T. V., and Charlson, R. J.: Primary particle emissions from residential coal burning: Optical properties and size distributions, J. Geophys. Res., 107, 8347, doi:10.1029/2001JD000571, 2002.

Canteenwalla, P. M., Thomson, K., Smallwood, G., and Johnson, M. R.: Sampling of soot emitted from lab-scale flares, NRC Publications Archive (NPArC), National Research Council Canada, 2006.

Chandrasekaran, S. R., Laing, J. R., Holsen, T. M., Raja, S., and Hopke, P. K.: Emission Characterization and Efficiency Measurements of High-Efficiency Wood Boilers, Energ. Fuel., 25, 5015-5021, 2011.

Chen, W.-T., Lee, Y. H., Adams, P. J., Nenes, A., and Seinfeld, J. H.: Will black carbon mitigation dampen aerosol indirect forcing?, Geophys. Res. Lett., 37, L09801, doi:10.1029/2010GL042886, 2010.

Cofala, J., Amann, M., Klimont, Z., Kupiainen, K., and HöglundIsaksson, L.: Scenarios of global anthropogenic emissions of air pollutants and methane until 2030, Atmos. Environ., 41, 84868499, 2007.

Dahl, A., Gharibi, A., Swietlicki, E., Gudmundsson, A., Bohgard, M., Ljungman, A., Blomqvist, G., and Gustafsson, M.: Trafficgenerated emissions of ultrafine particles from pavement-tire interface, Atmos. Environ., 40, 1314-1323, 2006.

Denier van der Gon, H., Visschedijk, A., Johansson, C., Hedberg Larsson, E., Harrison, R. M., and Beddows, D.: Size-resolved Pan European Anthropogenic Particle Number Inventory, EUCAARI Deliverable 141, 2009.

Denier van der Gon, H., Visschedijk, A., Johansson, C., Ntziachristos, L., and Harrison, R. M.: Size-resolved Pan-European Anthropogenic Particle Number Inventory, paper presented at International Aerosol conference (oral), 29 August 3 September 2010, Helsinki, 2010.

Denier van der Gon, H. A. C., Visschedijk, A., Johansson, C., Samaras, Z., Ntziachristos, L., and Paasonen, P.: Ultrafine particle emissions from residential combustion in Europe and their dependence on fuel quality and appliance type, 4th EFCA Ultrafine Particles Symposium 2013, Brussels, 2013.

Denier van der Gon, H. A. C., Visschedijk, A. J. H., Kuenen, J., Schieberle, C., Vouitsis, I., Samaras, Z., Moldanova, J., and Petzold, A.: European particle number emissions for 2005, 2020 and 2030 with special emphasis on the transport sector,9th International Conference on Air Quality - Science and Application, Garmisch-Partenkirchen, Germany, 2014.

Dentener, F., Kinne, S., Bond, T., Boucher, O., Cofala, J., Generoso, S., Ginoux, P., Gong, S., Hoelzemann, J. J., Ito, A., Marelli, L., Penner, J. E., Putaud, J.-P., Textor, C., Schulz, M., van der Werf, G. R., and Wilson, J.: Emissions of primary aerosol and precursor gases in the years 2000 and 1750 prescribed data-sets for Ae-
roCom, Atmos. Chem. Phys., 6, 4321-4344, doi:10.5194/acp-64321-2006, 2006.

Diesch, J.-M., Drewnick, F., Klimach, T., and Borrmann, S.: Investigation of gaseous and particulate emissions from various marine vessel types measured on the banks of the Elbe in Northern Germany, Atmos. Chem. Phys., 13, 3603-3618, doi:10.5194/acp-133603-2013, 2013.

Etissa, D., Mohr, M., Schreiber, D., and Buffat, P. A.: Investigation of particles emitted from modern 2-stroke scooters, Atmos. Environ., 42, 183-195, 2008.

European Commission: Communication from the commission to the council and the European parliament - Thematic Strategy on air pollution, available at: http://ec.europa.eu/environment/ archives/cafe/pdf/strat_com_en.pdf (last access: 17 May 2016), 2005.

Fountoukis, C., Riipinen, I., Denier van der Gon, H. A. C., Charalampidis, P. E., Pilinis, C., Wiedensohler, A., O’Dowd, C., Putaud, J. P., Moerman, M., and Pandis, S. N.: Simulating ultrafine particle formation in Europe using a regional CTM: contribution of primary emissions versus secondary formation to aerosol number concentrations, Atmos. Chem. Phys., 12, 86638677, doi:10.5194/acp-12-8663-2012, 2012.

Gaegauf, C., Wieser, U., and Macquat, Y.: Field investigation of nanoparticle emissions from various biomass combustion systems, in: Aerosols from Biomass Combustion, edited by: Nussbaumer, T., Presented at the International Seminar at 27 June 2001 in Zurich by IEA Bioenergy Task 32 and Swiss Federal Office of Energy, Verenum, Zurich, 2001.

Gultepe, I. and Isaac, G. A.: Scale Effects on Averaging of Cloud Droplet and Aerosol Number Concentrations: Observations and Models, J. Climate, 12, 1268-1279, 1999.

Hedberg, E., Kristensson, A., Ohlsson, M., Johansson, C., Johansson, P., Swietlicki, E., Vesely, V., Wideqvist, U., and Westerholm, R.: Chemical and physical characterization of emissions from birch wood combustion in a wood stove, Atmos. Environ., 36, 4823-4837, 2002.

Hobbs, P. V., Garrett, T. J., Ferek, R. J., Strader, S. R., Hegg, D. A., Frick, G. M., Hoppel, W. A., Gasparovic, R. F., Russell, L. M., Johnson, D. W., O’Dowd, C., Durkee, P. A., Nielsen, K. E., and Innis, G.: Emissions from ships with respect to their effects on clouds, J. Atmos. Sci., 57, 2570-2590, 2000.

Johansson, C., Hedberg, E., Boman, E., Denier van der Gon, H. A. C., and Visschedijk, A.: Review of particle number emission factors for residential biomass burning, ITM Report 176, 2008.

Johansson, L. S., Leckner, B., Gustavsson, L., Cooper, D., Tullin, C., and Potter, A.: Emission characteristics of modern and oldtype residential boilers fired with wood logs and wood pellets, Atmos. Environ., 38, 4183-4195, 2004.

Kasper, A., Aufdenblatten, S., Forss, A., Mohr, M., and Burtscher, H.: Particulate emissions from a low-speed marine diesel engine, Aerosol Sci. Tech., 41, 24-32, 2007.

Kerminen, V.-M., Pirjola, L., and Kulmala, M.: How significantly does coagulational scavenging limit atmospheric particle production?, J. Geophysi. Res., 106, 24119-24126, doi:10.1029/2001JD000322, 2001.

Kholghy, M., Saffaripour, M., Yip, C., and Thomson, M. J.: The evolution of soot morphology in a laminar coflow diffusion flame of a surrogate for Jet A-1, Combust. Flame, 160, 2119-2130, doi:10.1016/j.combustflame.2013.04.008, 2013. 
Kinsey, J. S., Kariher, P. H., and Dong, Y.: Evaluation of methods for the physical characterization of the fine particle emissions from two residential wood combustion appliances, Atmos. Environ., 43, 4959-4967, 2009.

Kiesewetter, G., Borken-Kleefeld, J., Schöpp, W., Heyes, C., Thunis, P., Bessagnet, B., Terrenoire, E., Gsella, A., and Amann, M.: Modelling $\mathrm{NO}_{2}$ concentrations at the street level in the GAINS integrated assessment model: projections under current legislation, Atmos. Chem. Phys., 14, 813-829, doi:10.5194/acp-14813-2014, 2014.

Klimont, Z., Cofala, J., Bertok, I., Amann, M., Heyes, C., and Gyarfas, F.: Modelling Particulate Emissions in Europe. A Framework to Estimate Reduction Potential and Control Costs (Interim Report No. IR-02-076), International Institute for Applied Systems Analysis (IIASA), Laxenburg, Austria, 2002.

Klimont, Z., Kupiainen, K., Heyes, C., Purohit, P., Cofala, J., Rafaj, P., Borken-Kleefeld, J., and Schoepp, W.: Global anthropogenic emissions of particulate matter including black carbon, in preparation, 2016a.

Klimont, Z., Höglund-Isaksson, L., Heyes, C., Rafaj, P., Schöpp, W., Cofala, J., Purohit, P., Borken-Kleefeld, J., Kupiainen, K., Kisewetter, G., Winiwarter, W., Amann, M, Zhao, B., Wang, S. X., Bertok, I., and Sander, R.: Global scenarios of air pollutants and methane: 1990-2050, in preparation, 2016b.

Kukkonen, J., Karl, M., Keuken, M. P., Denier van der Gon, H. A. C., Denby, B. R., Singh, V., Douros, J., Manders, A., Samaras, Z., Moussiopoulos, N., Jonkers, S., Aarnio, M., Karppinen, A., Kangas, L., Lützenkirchen, S., Petäjä, T., Vouitsis, I., and Sokhi, R. S.: Modelling the dispersion of particle numbers in five European cities, Geosci. Model Dev., 9, 451-478, doi:10.5194/gmd-9-4512016, 2016.

Kulmala, M., Asmi, A., Lappalainen, H. K., Baltensperger, U., Brenguier, J.-L., Facchini, M. C., Hansson, H.-C., Hov, Ø., O’Dowd, C. D., Pöschl, U., Wiedensohler, A., Boers, R., Boucher, O., de Leeuw, G., Denier van der Gon, H. A. C., Feichter, J., Krejci, R., Laj, P., Lihavainen, H., Lohmann, U., McFiggans, G., Mentel, T., Pilinis, C., Riipinen, I., Schulz, M., Stohl, A., Swietlicki, E., Vignati, E., Alves, C., Amann, M., Ammann, M., Arabas, S., Artaxo, P., Baars, H., Beddows, D. C. S., Bergström, R., Beukes, J. P., Bilde, M., Burkhart, J. F., Canonaco, F., Clegg, S. L., Coe, H., Crumeyrolle, S., D'Anna, B., Decesari, S., Gilardoni, S., Fischer, M., Fjaeraa, A. M., Fountoukis, C., George, C., Gomes, L., Halloran, P., Hamburger, T., Harrison, R. M., Herrmann, H., Hoffmann, T., Hoose, C., Hu, M., Hyvärinen, A., Hõrrak, U., Iinuma, Y., Iversen, T., Josipovic, M., Kanakidou, M., Kiendler-Scharr, A., Kirkevåg, A., Kiss, G., Klimont, Z., Kolmonen, P., Komppula, M., Kristjánsson, J.-E., Laakso, L., Laaksonen, A., Labonnote, L., Lanz, V. A., Lehtinen, K. E. J., Rizzo, L. V., Makkonen, R., Manninen, H. E., McMeeking, G., Merikanto, J., Minikin, A., Mirme, S., Morgan, W. T., Nemitz, E., O’Donnell, D., Panwar, T. S., Pawlowska, H., Petzold, A., Pienaar, J. J., Pio, C., Plass-Duelmer, C., Prévôt, A. S. H., Pryor, S., Reddington, C. L., Roberts, G., Rosenfeld, D., Schwarz, J., Seland, Ø., Sellegri, K., Shen, X. J., Shiraiwa, M., Siebert, H., Sierau, B., Simpson, D., Sun, J. Y., Topping, D., Tunved, P., Vaattovaara, P., Vakkari, V., Veefkind, J. P., Visschedijk, A., Vuollekoski, H., Vuolo, R., Wehner, B., Wildt, J., Woodward, S., Worsnop, D. R., van Zadelhoff, G.-J., Zardini, A. A., Zhang, K., van Zyl, P. G., Kerminen, V.-M., S Carslaw,
K., and Pandis, S. N.: General overview: European Integrated project on Aerosol Cloud Climate and Air Quality interactions (EUCAARI) - integrating aerosol research from nano to global scales, Atmos. Chem. Phys., 11, 13061-13143, doi:10.5194/acp11-13061-2011, 2011.

Kupiainen, K. and Klimont, Z.: Primary emissions of fine carbonaceous particles in Europe, Atmos. Environ., 41, 2156-2170, 2007.

Lack, D. A., Corbett, J. J., Onasch, T., Lerner, B., Massoli, P., Quinn, P. K., Bates, T. S., Covert, D. S., Coffman, D., Sierau, B., Herndon, S., Allan, J., Baynard, T., Lovejoy, E., Ravishankara, A. R., and Williams, E.: Particulate emissions from commercial shipping: Chemical, physical, and optical properties, J. Geophys. Res.-Atmos., 114, D00F04, doi:10.1029/2008JD011300, 2009.

Lamberg, H., Nuutinen, K., Tissari, J., Ruusunen, J., Yli-Pirilä, P., Sippula, O., Tapanainen, M., Jalava, P., Makkonen, U., Teinilä, K., Saarnio, K., Hillamo, R., Hirvonen, M.-R., and Jokiniemi, J.: Physicochemical characterization of fine particles from smallscale wood combustion, Atmos. Environ., 45, 7635-7643, 2011.

Lähde, T., Rönkkö, T., Virtanen, A., Solla, A., Kytö, M., Söderström, C., and Keskinen, J.: Dependence between nonvolatile nucleation mode particle and soot number concentrations in an EGR equipped heavy duty diesel engine exhaust, Environ. Sci. Technol., 44, 3175-3180, 2010.

Liggio, J., Gordon, M., Smallwood, G., Li, S.-M., Stroud, C., Staebler, R., Lu, G., Lee, P., Taylor, B., and Brook, J. R.: Are Emissions of Black Carbon from Gasoline Vehicles Underestimated? Insights from Near and On-Road Measurements, Environ. Sci. Technol., 46, 4819-4828, doi:10.1021/es2033845, 2012.

Makkonen, R., Asmi, A., Kerminen, V.-M., Boy, M., Arneth, A., Hari, P., and Kulmala, M.: Air pollution control and decreasing new particle formation lead to strong climate warming, Atmos. Chem. Phys., 12, 1515-1524, doi:10.5194/acp-12-15152012, 2012.

Moldanova, J., Fridell, E., Petzold, A., and Jalkanen, J.-P.: Report on shipping emission factors, TRANSPHORM Deliverable, D1.2.1, 2011.

Murphy, S. M., Agrawal, H., Sorooshian, A., Padro, L. T., Gates, H., Hersey, S., Welch, W. A., Jung, H., Miller, J. W., Cocker, D. R., Nenes, A., Jonsson, H. H., Flagan, R. C., and Seinfeld, J. H.: Comprehensive Simultaneous Shipboard and Airborne Characterization of Exhaust from a Modern Container Ship at Sea, Environ. Sci. Technol., 43, 4626-4640, 2009.

Ntziachristos, L., Pistikopoulos, P., and Samaras, Z.: Particle characterization from two-stroke powered two-wheelers, Int. J. Engine Res.h 6, 263-275, 2005.

Paasonen, P., Asmi, A., Petäjä, T., Kajos, M. K., Aijala, M., Junninen, H., Holst, T., Abbatt, J. P. D., Arneth, A., Birmili, W., van der Gon, H. D., Hamed, A., Hoffer, A., Laakso, L., Laaksonen, A., Leaitch, W. R., Plass-Duelmer, C., Pryor, S. C., Raisanen, P., Swietlicki, E., Wiedensohler, A., Worsnop, D. R., Kerminen, V.-M., and Kulmala, M.: Warming-induced increase in aerosol number concentration likely to moderate climate change, Nat. Geosci., 6, 438-442, 2013a.

Paasonen, P., Visschedijk, A., Kupiainen, K., Klimont, Z., Denier van der Gon, H., Kulmala, M., and Amann, M.: Aerosol particle number emissions and size distributions: Implementation in the GAINS model and initial results. Interim Report, IIASA, Laxenburg, Austria, IR-13-020, 2013b. 
Pope, C. A., Burnett, R., Thun, M. J., Calle, E. E., Krewski, D., Ito, K., and Thurston, G. D.: Lung cancer, cardiopulmonary mortality and long-term exposure to fine particulate air pollution, J. Am. Med. Assoc., 287, 1132-1141, 2002.

Pope, C. A., Ezzati, M., and Dockery, D. W.: Fine-particulate air pollution and life expectancy in the United States, New Engl. J. Med., 360, 376-386, 2009.

Samaras, Z., Ntziachristos, L., Thompson, N., Hall, D., Westerholm, R., and Boulter, P.: PARTICULATES (Characterisation of Exhaust Particulate Emissions from Road Vehicles, EC FP5), final report, available at: http://lat.eng.auth.gr/particulates/ deliverables/Particulates_D16.pdf (last access: 17 May 2016), 2005.

Pettersson, E., Boman, C., Westerholm, R., Boström, D., and Nordin, A.: Stove Performance and Emission Characteristics in Residential Wood Log and Pellet Combustion, Part 2: Wood Stove, Energ. Fuel., 25, 315-323, 2011.

Petzold, A., Hasselbach, J., Lauer, P., Baumann, R., Franke, K., Gurk, C., Schlager, H., and Weingartner, E.: Experimental studies on particle emissions from cruising ship, their characteristic properties, transformation and atmospheric lifetime in the marine boundary layer, Atmos. Chem. Phys., 8, 2387-2403, doi:10.5194/acp-8-2387-2008, 2008.

Pirjola, L., Karl, M., Rönkkö, T., and Arnold, F.: Model studies of volatile diesel exhaust particle formation: are organic vapours involved in nucleation and growth?, Atmos. Chem. Phys., 15, 10435-10452, doi:10.5194/acp-15-10435-2015, 2015.

Rodríguez, S. and Cuevas, E.: The contributions of "minimum primary emissions" and "new particle formation enhancements" to the particle number concentration in urban air, J. Aerosol Sci., 38, 1207-1219, doi:10.1016/j.jaerosci.2007.09.001, 2007.

Rodríguez, S., Van Dingenen, R., Putaud, J.-P., Dell'Acqua, A., Pey, J., Querol, X., Alastuey, A., Chenery, S., Ho, K.-F., Harrison, R., Tardivo, R., Scarnato, B., and Gemelli, V.: A study on the relationship between mass concentrations, chemistry and number size distribution of urban fine aerosols in Milan, Barcelona and London, Atmos. Chem. Phys., 7, 2217-2232, doi:10.5194/acp-72217-2007, 2007.

Rönkkö, T., Virtanen, A., Kannosto, J., Keskinen, J., Lappi, M., and Pirjola, L.: Nucleation Mode Particles with a Nonvolatile Core in the Exhaust of a Heavy Duty Diesel Vehicle, Environ. Sci. Technol., 41, 6384-6389, 2007.

Rönkkö, T., Lähde, T., Heikkilä, J., Pirjola, L., Bauschke, U., Arnold, F., Schlager, H., Rothe, D., Yli-Ojanperä, J., and Keskinen, J.: Effect of gaseous sulphuric acid on diesel exhaust nanoparticle formation and characteristics, Environ. Sci. Technol., 47, 11882-11889, doi:10.1021/es402354y, 2013.

Sinha, P., Hobbs, P. V., Yokelson, R. J., Christian, T. J., Kirchstetter, T. W., and Bruintjes, R.: Emissions of trace gases and particles from two ships in the southern Atlantic Ocean, Atmos. Environ., 37, 2139-2148, 2003.
Sorensen, C. M. and Feke, G. D.: The Morphology of Macroscopic Soot, Aerosol Sci. Tech., 25, 328-337, doi:10.1080/02786829608965399, 1996.

Stocker, T. F., Qin, D., Plattner, G.-K., Alexander, L. V., Allen, S. K., Bindoff, N. L., Breìn, F.-M., Church, J. A., Cubasch, U., Emori, S., Forster, P., Friedlingstein, P., Gillett, N., Gregory, J. M., Hartmann, D. L., Jansen, E., Kirtman, B., Knutti, R., Krishna Kumar, K., Lemke, P., Marotzke, J., Masson-Delmotte, V., Meehl, G. A., Mokhov, I. I., Piao, S., Ramaswamy, V., Randall, D., Rhein, M., Rojas, M., Sabine, C., Shindell, D., Talley, L. D., Vaughan, D. G., and Xie, S.-P.: Technical Summary, in: Climate Change 2013: The Physical Science Basis. Contribution of Working Group I to the Fifth Assessment Report of the Intergovernmental Panel on Climate Change, edited by: Stocker, T. F., Qin, D., Plattner, G.-K., Tignor, M., Allen, S. K., Boschung, J., Nauels, A., Xia, Y., Bex, V., and Midgley, P. M., Cambridge University Press, Cambridge, United Kingdom and New York, NY, USA, 2013.

Stohl, A., Aamaas, B., Amann, M., Baker, L. H., Bellouin, N., Berntsen, T. K., Boucher, O., Cherian, R., Collins, W., Daskalakis, N., Dusinska, M., Eckhardt, S., Fuglestvedt, J. S., Harju, M., Heyes, C., Hodnebrog, Ø., Hao, J., Im, U., Kanakidou, M., Klimont, Z., Kupiainen, K., Law, K. S., Lund, M. T., Maas, R., MacIntosh, C. R., Myhre, G., Myriokefalitakis, S., Olivié, D., Quaas, J., Quennehen, B., Raut, J.-C., Rumbold, S. T., Samset, B. H., Schulz, M., Seland, Ø., Shine, K. P., Skeie, R. B., Wang, S., Yttri, K. E., and Zhu, T.: Evaluating the climate and air quality impacts of short-lived pollutants, Atmos. Chem. Phys., 15, 10529-10566, doi:10.5194/acp-15-10529-2015, 2015.

Vouitsis, I., Ntziachristos, L., and Han, Z.: Methodology for the quantification of road transport PM emissions, using emission factors or profiles, TRANSPHORM Deliverable D1.1.2, 2013.

Weitkamp, E. A., Lipsky, E. M., Pancras, P. J., Ondov, J. M., Polidori, A., Turpin, B. J., and Robinson, A. L.: Fine particle emission profile for a large coke production facility based on highly time-resolved fence line measurements, Atmos. Environ., 39, 6719-6733, 2005.

Westervelt, D. M., Horowitz, L. W., Naik, V., Golaz, J.-C., and Mauzerall, D. L.: Radiative forcing and climate response to projected 21st century aerosol decreases, Atmos. Chem. Phys., 15, 12681-12703, doi:10.5194/acp-15-12681-2015, 2015.

WHO (World Health Organization): Review of Evidence on Health Aspects of Air Pollution - REVIHAAP project, Technical Report, World Health Organization 2013, available at: http://www.euro.who.int/_data/assets/pdf_file/0020/ 182432/e96762-final.pdf (last access: 27 March 2013), 2013.

Wigley, T. M. L.: Possible climate change due to $\mathrm{SO}_{2}$ derived cloud condensation nuclei, Nature, 339, 365-367, doi:10.1038/339365a0, 1989. 